\title{
Synergies and trade-offs in renewable energy landscapes: Balancing energy production with economics and ecosystem services
}

\author{
Rebecca J. Hanes*, Varsha Gopalakrishnan, and Bhavik R. Bakshi ${ }^{\dagger}$ \\ William G. Lowrie Department of Chemical and Biomolecular Engineering, \\ The Ohio State University, Columbus, OH, 43210 USA
}

\begin{abstract}
Sustainable design methods focus on reducing or minimizing the demand for ecosystem goods and services, quantified as natural resources and pollutant mitigation. However, the capacity of ecosystems to supply these demands is routinely ignored, leading to decisions that overburden ecological processes and cause environmental damage. This work develops a techno-ecological synergy (TES) design methodology that balances the ecosystem services that can be provided by nature with the ecosystem service demands created by human activities. The methodology includes the design of technological processes that require ecosystem services as well as the ecological processes that supply those services. The TES design methodology is demonstrated by application to a renewable energy production system that includes both land use activities, such as agriculture and wind turbines, and biomass conversion activities such as corn ethanol and soybean biodiesel. Under TES Design, the system is optimized to balance the demand and supply of ecosystem services, within constraints imposed on energy production and system economics. The system is also optimized under a more conventional approach that reduces ecosystem service demand while neglecting ecosystem service supply and the relevant ecological processes. Results show that only the TES methodology produces system designs in which ecosystem service supply meets or exceeds the demand. TES system designs produce the same amount of energy as conventional designs, have similar system economics, and use land both for energy production and for ecosystem service supply. The additional supply enables the use of intensive agricultural practices with higher ecosystem service demands and higher biomass yields. These results encourage further efforts toward TES Design with additional ecosystem services.
\end{abstract}

${ }^{*}$ Currently at the National Renewable Energy Laboratory, Golden, CO, USA

${ }^{\dagger}$ Corresponding author; email: bakshi.2@osu.edu; tel: +1 614-292-4904 


\section{Keywords}

Ecosystem services

Sustainability

Renewable energy

Land use trade-offs

\section{Introduction}

Human activities are sustained by ecosystem services, the resources and benefits provided by natural systems. [1] Ecosystem services include tangible goods, including clean water and crops, as well as less tangible but equally vital benefits such as carbon sequestration, air quality regulation and biodiversity. All human activities create ecosystem service demands, whether through emitting pollutants such as greenhouse gases or through the use of natural and agricultural resources. At present, the demands for ecosystem services created by human activity far outstrips the available ecosystem service supply, which is the capacity of ecosystems to sequester pollutants and provide the required natural goods. [2,3] This situation, called ecological overshoot, has resulted in adverse consequences for humans and for ecosystems, including climate change, soil erosion and quality degradation, and decreases in water quality. [4]

A variety of design methods in different fields of study have been developed to address the interdependencies between ecosystem services and human activity, with the goal of reducing the existing ecological overshoot. Some methods address the role of ecosystem services in agriculture, and explore agricultural management practices and alternate crops that support ecosystem service supply while still providing necessary food, fiber and feedstocks. [5,6] In the field of engineering, sustainable design methods have been developed that optimize technological systems to minimize ecosystem service demand, generally quantified as greenhouse gases or other emissions, at the life cycle scale. $[7,8]$

These previously developed methods can be used to make decisions that increase relative sustainability by reducing environmental impacts and ecosystem dis-services. However, it is unlikely that these methods will lead to absolute sustainability, in which ecosystem service supply meets or exceeds the demand for all relevant ecosystem services. Achieving absolute sustainability, which can also be defined as a state of zero ecological overshoot, will require methods that simultaneously reduce ecosystem service demand and increase the available supply, by developing synergies between technological and ecological systems. Multiple ecosystem services must be considered, in a rigorous and quantitative manner, and a multi-scale or life cycle boundary must be used, both to avoid shifting ecosystem service demands outside of the analysis boundary and to capture ecosystem services at the appropriate scale.

In this paper the concept of techno-ecological synergy (TES) is used to develop a design methodology that incorporates simultaneous technological and ecological decision making, a life cycle system boundary, and both demand and supply for multiple ecosystem services. [9] The proposed TES design methodology is demonstrated by application to a renewable energy production system located in central Ohio. Renewable energy systems were chosen as the application in this work because the sustainability - as well as the economic and technical feasibility - of such systems depends upon balanced interactions between technological and ecological processes. [10,11] However, the present methodology is intended as a special case of a general TES design methodology, still under development, that can be applied to design any type of system at any scale, from a single private home to a regional biofuel supply chain or national renewable electricity grid. 
Results of applying the TES design methodology to a renewable energy system will demonstrate three benefits of TES design. First, TES design leads to unique designs with higher sustainability compared to conventional life cycle design. Second, the use of TES in designing renewable energy systems enables identification of synergies between the technological and ecological system components that are not apparent under life cycle designs and other technology-centric designs. Finally, the use of TES in design allows for the evaluation of trade-offs between multiple objectives: monetary value, renewable energy production, and the ecosystem services air quality regulation and climate regulation. Under TES design, intensive agricultural farming practices are used to produce biomass efficiently, and the ecosystem service demands created by these practices are offset by additional land used to create ecosystem service supply. While the purpose of this work is not to make policy recommendations or to promote one kind of renewable energy over others, knowledge of the trade-offs between the many goods and services provided by land use can be applied to determine how much value can be economically and sustainably extracted from the land.

The literature review in Section 2 provides an overview of studies that incorporate aspects of TES, in order to convey the novelty and uniqueness of the proposed approach. Section 3 presents the methodology for applying TES design to a renewable energy system. Key results that demonstrate the benefits of TES design are discussed in Section 4, with additional results presented in the Annexes. Section 5 presents conclusions of this work and discusses future work.

\section{Literature Review}

The five core concepts of TES design described in Section 1 are, by themselves, not novel; the novelty of this work is that these five concepts have not previously been integrated into a cohesive methodology for application to a single design problem. This section gives an overview of recent studies that use at least two of the five TES concepts in a design context. Table 1 lists these studies along with the corresponding TES concepts.

Zhang et al. [12] developed a modeling framework to optimize biofuel feedstock production while accounting for trade-offs between agricultural productivity and demand for several ecosystem services; however, the supply of only one ecosystem service, carbon sequestration, was quantified. Eranki et al. [13] develop a similar model to design a cellulosic biofuel feedstock supply chain by allocating land to feedstock production, with the additional constraint that animal nutrition needs also be met. This study incorporated a life cycle assessment of the supply chains being designed and also quantified multiple ecosystem services, although the balance between demand and supply for individual services was not considered. Meehan et al. [14] modeled ecosystem service tradeoffs of using the same land for either corn or perennial grasses, and considered both potential energy production and feedstock economics. In a similar study, Davis et al. [15] quantified the ecosystem service impacts of land used to produce different biofuel feedstocks. Behrman et al. [16] and Meyer et al. [17] also consider land use for biofuel, but quantify only the impacts on ecosystem service supply. Although the focus of these studies is on supplying feedstock to biofuel or bioenergy production, none of these studies consider technological design variables, and in each study the type of feedstock and energy product produced is fixed. With the exception of [13], these studies also neglect the life cycle of the systems being designed, which can lead to environmental impacts and ecosystem disservices being shifted outside the analysis boundary rather than being avoided altogether.

Studies that focus primarily on technological design include You et al. [18], Čuček et al. [19] and Hanes and Bakshi [20], among many other similar works. You et al. combine a supply chain model with a life cycle assessment of the supply chain in order to optimize the supply chain and its life cycle for minimum emissions. Čuček et al. take a similar approach to select biomass conversion 
Table 1: Previous studies that incorporate one or more aspects of TES design.

\begin{tabular}{c|c|c|c|c|c}
\hline Source & $\begin{array}{c}\text { Technological } \\
\text { Design }\end{array}$ & $\begin{array}{c}\text { Ecological } \\
\text { Design }\end{array}$ & $\begin{array}{c}\text { Life Cycle } \\
\text { Scale }\end{array}$ & $\begin{array}{c}\text { Ecosystem } \\
\text { Service Demand }\end{array}$ & $\begin{array}{c}\text { Ecosystem } \\
\text { Service Supply }\end{array}$ \\
\hline This work & $\mathrm{X}$ & $\mathrm{X}$ & $\mathrm{X}$ & $\mathrm{X}$ & $\mathrm{X}$ \\
\hline$[12]$ & & $\mathrm{X}$ & & $\mathrm{X}$ & $\mathrm{X}$ \\
{$[13]$} & & $\mathrm{X}$ & $\mathrm{X}$ & $\mathrm{X}$ & $\mathrm{X}$ \\
{$[14]$} & & $\mathrm{X}$ & & $\mathrm{X}$ & $\mathrm{X}$ \\
{$[15]$} & & $\mathrm{X}$ & & $\mathrm{X}$ & $\mathrm{X}$ \\
{$[16]$} & & $\mathrm{X}$ & & & $\mathrm{X}$ \\
{$[17]$} & & $\mathrm{X}$ & & $\mathrm{X}$ \\
{$[18]$} & $\mathrm{X}$ & $\mathrm{X}$ & $\mathrm{X}$ & $\mathrm{X}$ & \\
{$[19]$} & $\mathrm{X}$ & $\mathrm{X}$ & $\mathrm{X}$ & $\mathrm{X}$ & \\
{$[20]$} & $\mathrm{X}$ & $\mathrm{X}$ & $\mathrm{X}$ & $\mathrm{X}$ & \\
{$[21]$} & $\mathrm{X}$ & $\mathrm{X}$ & $\mathrm{X}$ & $\mathrm{X}$ & \\
{$[22]$} & $\mathrm{X}$ & $\mathrm{X}$ & $\mathrm{X}$ & $\mathrm{X}$ & $\mathrm{X}$ \\
{$[23]$} & & $\mathrm{X}$ & $\mathrm{X}$ & $\mathrm{X}$ \\
{$[24]$} & & & $\mathrm{X}$ & $\mathrm{X}$ \\
{$[25]$} & & & & \\
{$[26]$} & & & & \\
\hline
\end{tabular}

technologies according to environmental impacts at the life cycle scale. Hanes and Bakshi use a multi-scale model to minimize emissions from an ethanol plant and its life cycle within a national system boundary. While each of these studies includes the technological design variables and life cycle that the previous set of studies largely lacked, ecosystem service supply and ecological design are uniformly excluded. These studies thus risk making decisions that minimize environmental impacts and ecosystem service demand but still do not approach absolute sustainability, due to the ecosystem service demand still far outweighing the available supply.

Some more general studies have also focused on developing frameworks that can predict the complex interplay between changes in ecosystem services and energy production systems. Howard et al. [21] developed a framework for incorporating the entire energy landscape including supply, demand and infrastructure available for energy production at a local scale, and measured how these systems interact with ecosystem services. However, main focus of this work was to build a framework for decision making by accounting for stakeholder preferences and not for identifying optimal design pathways. Guo et al. [22] developed a modeling framework that considers the competition between land used by different economic sectors, and the impacts of land-use change on multiple ecosystem services across the entire value chain. Gonzalez et al. [23] developed a modeling framework accounting for the interactions between energy, economy, land use and greenhouse gas emissions for emerging bioenergy production systems in developing countries. However, the latter two frameworks do not account for the entire life cycle of the system and ignore the ecosystem service supply entirely.

Finally, there have been several studies that focus on quantifying the interactions between technological systems and ecosystems via quantification of ecosystem service demand and supply. Gopalakrishnan et al. [24] assessed the importance of ecosystem services in supporting an industrial 
site by quantifying the demand and supply of multiple ecosystem services at a local scale. However, this study does not account for life cycle emissions and ignores aspects of technological design. Urban et al. [25] designed a techno-ecological North American residential system by accounting for both demand and supply of ecosystem services, and included behavioral, ecological and technological decision variables. Martinez-Hernandez et al. [26] used a system dynamics approach to analyze the impacts of bioenergy production on services provided by a dynamic heathland ecosystem. The latter two studies incorporate all aspects of TES design except for the life cycle boundary. Solutions found in these studies therefor risk shifting the ecosystem service demand to activities outside the analysis boundary.

The studies and methods discussed above are each missing some key aspect of TES design and therefore solve only part of the problem, and in so doing are likely to lead to sub-optimal or simply incorrect solutions [27]. The primary contribution of this work, the TES design methodology, is an attempt to solve the entire problem, by framing the design problem in terms of achieving balance between demands placed on ecosystems and the ability of ecosystems to satisfy those demands, while still maintaining a profitable and productive system.

\section{Materials and Methods}

In this section, methods for applying TES in a design context and for building a renewable energy system model for optimization are discussed. Details on the specific model built in this work are given, along with the source data and assumptions used in building the model. Finally, the optimization formulation used to solve the model and generate renewable energy system designs is discussed.

\subsection{Techno-ecological synergy design concept}

The TES design methodology is used to make simultaneous technological and ecological design decisions within a multi-scale system in order to both decrease demand and increase supply of multiple ecosystem services. [9] This is intended to avoid the risk of identifying sub-optimal design decisions that either shift ecosystem service demand and the accompanying environmental impacts outside the system boundary, or decrease ecosystem service demand without considering if the decreased demand can be sustainably supplied by supporting ecosystems. TES design also promotes land use and other activities that preserve and restore ecological functions and increase the available ecosystem service supply. TES design is in contrast with the more conventional life cycle design, in which a technological system is designed within its life cycle to minimize ecosystem service demand and the role of ecological systems in supporting the technological system is neglected. Specific TES design requirements, contrasted with the requirements for conventional life cycle based design, are given in Table 2 .

The TES design methodology requires modeling systems at multiple scales. The scale of ecological systems varies from local, regional to global depending on the serviceshed of the ecosystem service of interest, which is the maximum scale at which the ecosystem service can be supplied. [9,28] Typically, ecosystem services like water quality regulation are modeled at the local or regional (watershed) scale, while services like carbon sequestration, with global servicesheds, can be modeled at the local, regional and global scales. Some ecosystem services, such as pollination, have servicsheds limited by the area traveled by pollinators and are modeled at smaller scales. The supply of smaller-scale ecosystem services is also spatially specific and depends on multiple factors such as local meteorological conditions, land use practices and the availability of ecological systems at a given scale. Technological systems can vary from individual processes at the local scale to aggregate 
Table 2: Requirements for TES design contrasted with conventional life cycle design.

\begin{tabular}{|c|c|}
\hline TES Design & Life Cycle Design \\
\hline $\begin{array}{l}\text { - Simultaneous design of technological } \\
\text { and ecological systems } \\
\text { - Inclusion of ecosystem service de- } \\
\text { mand and ecosystem service supply in } \\
\text { design criteria } \\
\text { - Inclusion of multiple ecosystem ser- } \\
\text { vices and goods (bundles) in design cri- } \\
\text { teria } \\
\text { - Consideration of technological and } \\
\text { ecological systems at multiple scales, up } \\
\text { to the life cycle or larger scale }\end{array}$ & $\begin{array}{l}\text { - Design of technological systems } \\
\text { - Inclusion of ecosystem service de- } \\
\text { mand in design criteria } \\
\text { - Occasional inclusion of multiple } \\
\text { ecosystem services in design criteria } \\
\text { - Consideration of technological sys- } \\
\text { tems up to the life cycle scale }\end{array}$ \\
\hline
\end{tabular}

activities at the larger, life cycle scale. Within a particular spatial scale, both the technological systems that create ecosystem service demand and the corresponding ecological systems that create the ecosystem service supply should be included. The expanded system boundary enables the identification and exploitation of synergies and trade-offs between technological and ecological systems, as well as synergies and trade-offs between the various ecosystem services and between systems at different scales.

TES design requires quantifying ecosystem service demand and supply at each relevant spatial scale, in order to determine the extent to which the demand for an ecosystem service overshoots the supply and to make decisions that decrease or eliminate the overshoot. The sustainability index $V_{j k}$ is a TES metric defined for each ecosystem service $k$ at each relevant spatial scale $j$ that quantifies this overshoot: [9]

$$
V_{j k}=\frac{S_{j k}-D_{j k}}{D_{j k}}
$$

In Equation 1, $D_{j k}$ is the demand for ecosystem service $k$, and $S_{j k}$ is the supply. As discussed in Section 1, ecosystem service demand is quantified by resource use or emissions, while supply is quantified by the capacity of an ecological system to supply the resources demanded or to mitigate the pollution produced.

The sustainability index $V_{j k}$ has multiple uses in the TES design methodology: as an indicator of the degree of unsustainability or sustainability, as an objective function, and as a metric to compare different systems and system designs. $V_{j k}$ is designed such that when Equation (2) holds true:

$$
V_{j k} \geq 0
$$

the supply of ecosystem service $k$ equals or exceeds the demand at scale $j$, which indicates sustainable use of service $k$. More strongly, when Equation (2) holds true at a scale $j$ equal to the serviceshed of service $k$, this indicates absolute sustainability for service $k$. In contrast, a negative $V_{j k}$ indicates unsustainable use of service $k$. The minimum value of $V_{j k}$ is -1 , which indicates that no significant supply of service $k$ is available at scale $j$. When $V_{j k}<0$, ecosystems cannot supply sufficient services to meet the demand created by technological systems without causing harmful ecological degradation and a further decrease in the ecosystem's ability to supply the necessary services. For instance, $V_{j k}<0$ for carbon sequestration at the local scale indicates that local ecosystems do not have the capacity to mitigate the greenhouse gas emissions being produced, 
and the technological system must depend on carbon sequestration supplied from larger scales or different geographic locations.

\subsection{Options for renewable energy production}

Two general categories of activities must be included in the design of a renewable energy production system. First is land use activities, which may be agricultural activities that produce biomass feedstocks to be converted to energy carriers, or technological activities that produce electricity or heat directly. Land use activities may also supply ecosystem services in addition to or instead of supplying biomass or energy. The second activity category is biomass conversion activities, which convert biomass feedstocks into electricity, heat or biofuels. Exactly which activities to consider in each category should be informed by the geographic location of the system being designed, along with the meteorological and agricultural characteristics of that location. The economic and technical feasibility of each activity should also be considered, particularly how the activity's feasibility is affected by the geographic location. For instance, concentrated solar power (CSP) is a land use activity that generates electricity is becoming more feasible as the technology advances, but even if CSP becomes cheap and reliable in the desert regions of the American Southwest, it will not be economic in the cloudier, rainier Pacific Northwest region. Similarly, corn farming for starch or cellulosic ethanol is concentrated in the "Corn Belt," located in the American Midwest, because the climate and soil in that region grows corn very efficiently.

Because this work focuses on renewable energy in central Ohio, the land use and biomass conversion activities chosen reflect both activities that are already established in the region and those activities which have the potential to be economically and technically feasible, but are not yet established. The complete set of land use and biomass conversion activities considered, and the potential connections between activities, are shown in Figure 1. Land use activity options, in red in Figure 1, are continuous corn, corn-soybean rotation, and perennial switchgrass cropping systems, wind turbines and solar panels. Each cropping system activity is modeled under two types of farming practice, a standard, intensive farming practice (conventional tillage, switchgrass with nitrogen fertilizer) and conservation practice (no tillage, switchgrass without nitrogen fertilizer). The conservation farming practices are intended to promote ecosystem service supply at the farm scale. Additional land use activity options which solely supply ecosystem services are shown in green in Figure 1. These are all reforestation activities, with six native Ohio tree species. Each of the tree species supplies ecosystem services, although the growth rate and tree characteristics, which vary by species, determine which services are supplied and at what rate.

The biomass conversion activities, shown in blue in Figure 1, include both commercial processes and processes still in development or at the pilot stage. To correspond with the land use activities being considered, corn ethanol, cellulosic ethanol and soybean biodiesel are included, as are the less well-developed biomass pyrolysis and hydrotreating and biomass combustion. Each biomass conversion activity can utilize the feedstock from multiple land use activities, increasing the total number of possible energy production pathways in the design space.

\subsection{Design scenarios}

The energy production system is optimized under two design scenarios in order to compare and contrast the results of conventional life cycle design with the TES design methodology. These scenarios are based on the criteria laid out in Table 2. In the first scenario, Life Cycle Design, the model is optimized, separately, for economics, energy production, and the system's demand for key ecosystem services. Land can be used only for fuel and energy production; reforestation to create additional ecosystem service supply is not permitted. The supply of ecosystem services 


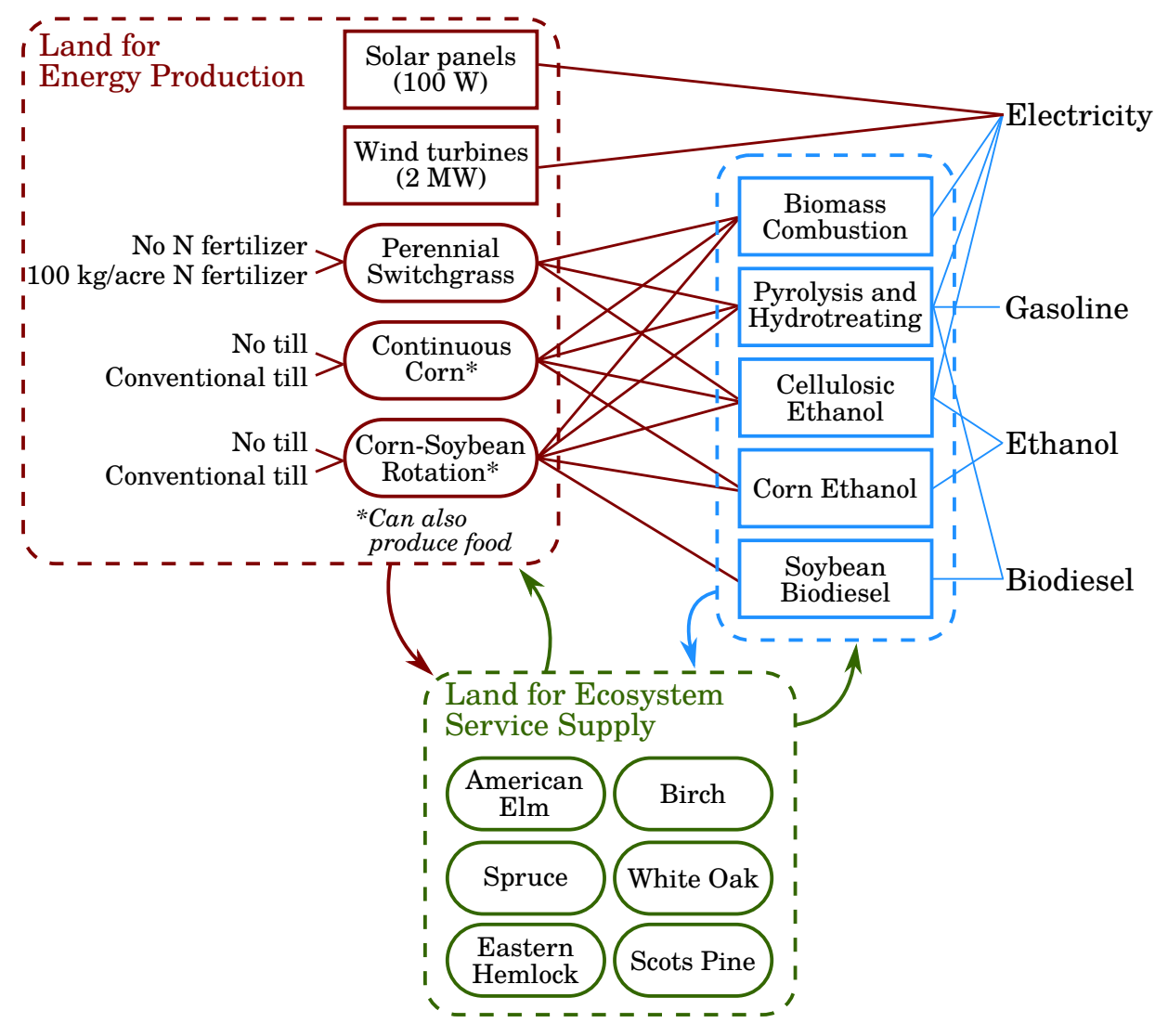

Figure 1: The renewable energy production system superstructure, which contains land use and biomass conversion activities for every energy production pathway considered. 
provided by agricultural land use activities is also not considered. In the second scenario, TES Design, the economics and energy production objective functions are identical to those under Life Cycle Design. However, instead of minimizing ecosystem service demand, net ecosystem service supply, quantified by supply minus demand, is maximized. Recall that ecosystem service supply is quantified as the ability of ecosystems to sequester or mitigate pollutants, while ecosystem service demand is quantified as pollutant production or natural resource consumption. Net ecosystem service supply is equal to the numerator of Equation (1) $\left(S_{j k}-D_{j k}\right)$; the numerator is optimized rather than Equation (1) to keep the model linear. TES Design also allows for land to be used for reforestation rather than energy production to increase the supply of ecosystem services. As the total amount of land available is the same in both design scenarios, land used for ecosystem service supply competes with land used for energy production.

\subsection{Model structure and constraints}

To determine the optimal combinations of land use activities and biomass conversion pathways, a mixed-integer linear program (MILP) representation of the superstructure shown in Figure 1 is developed. The MILP was solved a total of sixteen times. Solutions were found for four objective functions under the two design scenarios described in 3.3 and under each of two energy production constraints. Further details on the MILP, objective functions and design scenarios are given in this section. The model was implemented in Python and solved using lp_solve. [29]

The various combinations of activities in the energy production system, and the life cycles of those activities, are captured using the multi-scale process to planet (P2P) modeling framework. [30] The P2P framework connects component models at three different scales: local, regional and national. At the local scale, component models are detailed and specific to a technological process or facility. For instance, a local scale model might represent a particular biodiesel plant. Regional scale component models are less detailed and represent a regional, state or county-average activity, such as farming practices in a particular geographic area. The national scale component model, the least detailed, represents a national economy. Component models are connected by monetary and material exchanges and used to form a set of multi-scale mass, energy and monetary balances on the system and its life cycle:

$$
\left[\begin{array}{ccc}
\overline{\mathbf{I}}-\overline{\mathbf{A}}^{*} & -\underline{\mathbf{X}}_{u} & -\mathbf{X}_{u}^{E} \\
\underline{\mathbf{0}} & \underline{\mathbf{X}} & -\mathbf{X}_{u}^{V} \\
\mathbf{0} & \mathbf{0} & \mathbf{X}
\end{array}\right]\left[\begin{array}{l}
\overline{\mathbf{s}} \\
\mathbf{\mathbf { s }} \\
\mathbf{s}
\end{array}\right] \geq\left[\begin{array}{l}
\overline{\mathbf{0}} \\
\geq \\
\underline{\mathbf{0}} \\
\mathbf{0}
\end{array}\right]
$$

The vectors $\overline{\mathbf{s}}, \underline{\mathbf{s}}$ and $\mathbf{s}$ are decision variables at the national, regional and local scales respectively, and are defined in Section 3.11. Matrices in the first line of Equation (3) represent monetary flows that originate in economic sectors, at the national scale. $\overline{\mathbf{A}}^{*}$ is the disaggregated direct requirements matrix, derived from the 2002 benchmark input-output model of the U.S. economy developed by the Bureau of Economic Analysis. [31] $\overline{\mathbf{I}}$ is the identity matrix of the same dimensions as $\overline{\mathbf{A}}^{*}$. The original direct requirements matrix $\overline{\mathbf{A}}$ was disaggregated to $\overline{\mathbf{A}}^{*}$ to avoid double-counting land use and biomass conversion activities that are modeled at the regional and local scales respectively. [30]

$\underline{\mathbf{X}}_{u}$ in Equation (3) contains, in monetary units, the amounts of fertilizer, fuel and other inputs required by each land use activity per acre. $\underline{\mathbf{X}}_{u}$ also contains the purchase, installation and maintenance costs per unit for wind turbines and solar panels. The production and distribution of these flows, representing the life cycle of the land use activities, is captured at the national scale. Similarly, $\underline{\mathbf{X}}_{u}^{E}$ contains, also in monetary units, the amounts of fuels, chemicals, process equipment and other inputs required by the biomass conversion plants, and represents the life cycle of the 
biomass conversion plants. Taken together, the first line of Equation (3) represents a monetary balance on the national scale model, and is interpreted as stating that no flows leave the economy save for those required by the energy production activity models.

Matrices in the second line of Equation (3) represent physical unit flows originating in the land use activities, including the cropping systems, the wind turbines and the solar panels. $\underline{\mathbf{X}}$, in physical units, contains the biomass production per acre for the cropping systems and the electricity production per unit for wind turbines and solar panels. (Recall that inputs to the cropping systems, wind turbines and solar panels are modeled as flows originating in the economy and are represented in the matrix $\underline{\mathbf{X}}_{u}$.) $\mathbf{X}_{u}^{V}$, in physical units, contains the flows of biomass per plant for each biomass conversion process. The second line of Equation (3) thus represents a mass balance on corn, soybean and cellulosic biomass flows, and also represents the amount of electricity produced by wind turbines and solar panels. This line of the equation is constrained to be greater than or equal to zero, meaning that all type of biomass and particularly food products can be sold as is, instead of being converted to energy.

The third line of Equation (3) contains a physical-units matrix $\mathbf{X}$ that represents the end product yields for the biomass conversion processes. (Recall that non-biomass inputs to the plants are captured in $\mathbf{X}_{u}^{E}$ as monetary flows originating in the economy, and that the biomass inputs are captured in $\mathbf{X}_{u}^{V}$ as physical flows originating in the land use activities.) The third line of Equation (3) is also constrained to be greater than or equal to zero, allowing for energetic end products to leave the system. To simplify the analysis, all energetic products are assumed to be used for transportation. This assumption allows the energetic end products to be quantified in gasoline gallon equivalents (GGEs) and enables direct comparison between all possible system designs.

There are three zero matrices in Equation (3), forming the lower triangular matrix. These matrices represent flows back to the national scale that originate at the local and regional scales. Because these matrices consist of zeros, there are no such flows in the system model.

\subsection{Land use and reforestation constraints.}

The total acreage of all land use activities, including cropping systems, wind turbines and solar panels, and reforestation, is constrained to be less than or equal to 10,000 acres:

$$
\boldsymbol{\Lambda} \cdot\left[\begin{array}{l}
\underline{\mathbf{s}} \\
\underline{\mathbf{t}}
\end{array}\right] \leq 10,000 \text { acres }
$$

The elements of $\boldsymbol{\Lambda}$ are given in Table 9 .

The Life Cycle Design scenario does not allow for reforestation and an additional constraint on t:

$$
\underline{\mathbf{t}}=\mathbf{0}
$$

is necessary to constrain all elements of $\underline{\mathbf{t}}$ to zero. The TES Design scenario allows reforestation, thus Equation (4) is sufficient to constrain the land use activity acreage. Note that under TES Design, there is no explicit upper limit placed on the acres of reforestation. Instead, reforestation is implicitly constrained by the energy production and net present value constraints discussed below.

\subsection{Energy production and NPV constraints.}

Several constraints are imposed to restrict the design space under both scenarios to economically and technologically feasible systems. The NPV of the entire system, including agricultural activities, 
wind turbines and solar panels, reforested land and all biomass conversion processes, is constrained to be greater than or equal to zero:

$$
\mathbf{N} \cdot\left[\begin{array}{l}
\underline{\mathbf{s}} \\
\underline{\mathbf{t}} \\
\mathbf{s}
\end{array}\right] \geq 0
$$

The elements of $\mathbf{N}$ are given in Table 9. A lower limit is also imposed on the amount of energy produced by the system. Unlike the NPV constraint, two values of the energy production constraint are defined relative to the maximum possible energy production. Sets of solutions were found for energy production greater than or equal to $10 \%$ of the maximum:

$$
\mathbf{E} \cdot\left[\begin{array}{l}
\underline{\mathbf{s}} \\
\underline{\mathbf{t}} \\
\mathbf{s}
\end{array}\right] \geq 0.1 E_{\max }
$$

and for greater than or equal to $90 \%$ of the maximum:

$$
\mathbf{E} \cdot\left[\begin{array}{l}
\underline{\mathbf{s}} \\
\underline{\mathbf{t}} \\
\mathbf{s}
\end{array}\right] \geq 0.9 E_{\max }
$$

The two sets of solutions are referred to in subsequent sections as "Low Energy Production" and "High Energy Production" designs, respectively. Finding solutions for multiple values of this constraint rather than fixing the value allows for an analysis of trade-offs between energy productivity, ecosystem services and economics. The elements of $\mathbf{E}$ are given in Table 9. In Equations (7) and (8), $E_{\max }$ is defined as

$$
E_{\max }=9.59 \times 10^{7} \mathrm{GGE}
$$

The maximum energy production value was found by solving the MILP for maximum energy while constraining the NPV to be greater than or equal to zero. This is the maximum possible energy production from the system being considered, and does not change under different design scenarios.

\subsection{Biomass conversion, wind turbine and solar panel models}

Table 3 lists the sources of data used to build the biomass conversion process, wind turbine and solar panel models. Each biomass conversion process model contains a set of process inputs and energy outputs scaled to the consumption of one unit of biomass feedstock. Emissions factors from GREET 2015 were used to model process fuel combustion. [32] Prices for commodity chemical inputs were obtained from ICIS [33], and fuel and energy prices were obtained from the Energy Information Administration. [34-38] Prices for inputs that could not be found within these sources were obtained from online retailers. Where possible, input prices and other economic data were obtained for the year 2002; any prices not already at 2002 levels were converted using producer price index data from the U.S. Bureau of Labor Statistics. [39] Each plant's twenty-year NPV is calculated from the total installed equipment cost (obtained from sources cited in Table 3), the revenue from sales of energy products, and other economic parameters. [40]

To build the energy production system model, each of the biomass conversion process models was scaled to represent the maximum possible capacity of each plant. The maximum capacity was based on the maximum availability of each type of biomass feedstock. For instance, the corn ethanol process model was scaled to the amount of corn produced by the continuous corn, no till cropping system, which produced the most corn out of the four corn-producing cropping systems. Scaling the baseline process models in this way allows the models to be scaled linearly by the amount of 
Table 3: Summary of data sources for wind turbine, solar panel and biomass conversion process models.

\begin{tabular}{l|c}
\hline Model & Source(s) of model data \\
\hline Wind Turbine & {$[41-44]$} \\
Solar Panel & {$[41,45]$} \\
Corn Ethanol & {$[46,47]$} \\
Soybean Biodiesel & {$[32,48-51]$} \\
\hline Stover Ethanol & {$[46,47,52]$} \\
Switchgrass Ethanol & {$[53-55]$} \\
\hline Stover Pyrolysis & \\
Switchgrass Pyrolysis & {$[32,56]$} \\
\hline Stover Combustion & \\
Switchgrass Combustion & \\
\hline
\end{tabular}

available feedstock, which depends on the type and acreage of the active cropping systems, during optimization. The linear process scaling is not ideal, as economies of scale cannot be captured; this is particularly significant in calculating the economic objective function, which is the sum of the net present values of each system component. For this reason NPV is referred to as "Linearized NPV" in Section 4. Using linear scaling leads to very small-scale process models appearing to be more efficient and economical than they would be in reality. However, keeping the scaling linear also keeps the system model linear, which ensures that a global optimum will be found for each objective function.

The source data, including biomass conversion processes and all relevant input prices, were largely from 2002. The purpose of this work is to demonstrate that engineering design decisions made based on ecosystem services will change depending on whether only ecosystem service demand is considered or both supply and demand. The age of the data is thus expected to have little to no impact on the major conclusions of this work.

\subsection{Farming activity models}

Farming activities were modeled using the Environmental Policy Integrated Climate (EPIC) software for Windows (WinEPIC) $[57,58]$ to create a spatially specific model for each cropping system. As model inputs, WinEPIC requires spatially and temporally specific information on climate, $[59,60]$ farming management practices [61-63] and soil type [64]. To extend the meteorological data to cover the full twenty year time period, data for the first three years (1995 - 1998) was used as proxy data for the final years $(2011$ - 2014). All farming activities including fertilizer requirements, pesticide application rate and other farming decisions were identical each year, depending on the crop type. Default planting and harvesting calenders in WinEPIC were used to specify the dates of all plantings, fertilizer applications, harvests, and other activities. Given this input data, WinEPIC calculates carbon and nitrogen flows (including both sequestration and releases) and crop yields on both daily and annual bases.

Table 4 gives the climate regulation and air quality regulation demand and supply created by the cropping systems over twenty years, calculated using WinEpic as discussed above. The fertilized switchgrass cropping system has the highest climate regulation demand per acre, due to decaying crop residues that release $\mathrm{CO}_{2}$ emissions in addition to the $\mathrm{CO}_{2}$ and $\mathrm{N}_{2} \mathrm{O}$ emissions generated from the use of farming equipment. However, the climate regulation supply is also highest for this cropping system, as the crop residues also return carbon to the soil. Air quality regulation demand 
Table 4: Ecosystem service demand and supply for farming activities over twenty years.

\begin{tabular}{l|c|c|c|c}
\hline \multirow{2}{*}{ Cropping System } & \multicolumn{2}{|c|}{$\begin{array}{c}\text { Climate Regulation } \\
\left(\mathrm{kg} \mathrm{CO}_{2} \text {-eq/acre }\right)\end{array}$} & \multicolumn{2}{c}{$\begin{array}{c}\text { Air Quality Regulation } \\
\left(\mathrm{kg} \mathrm{NO} \mathrm{NO}_{2} / \text { acre }\right)\end{array}$} \\
\cline { 2 - 5 } & Demand & Supply & Demand & Supply \\
\hline Cont. Corn, No Till & $6.83 \times 10^{4}$ & $2.54 \times 10^{3}$ & $2.28 \times 10^{1}$ & 0 \\
Cont. Corn, Conv. Till & $7.30 \times 10^{4}$ & $2.48 \times 10^{3}$ & $3.72 \times 10^{1}$ & 0 \\
Corn-Soybean, No Till & $6.37 \times 10^{4}$ & $2.66 \times 10^{3}$ & $2.26 \times 10^{1}$ & 0 \\
Corn-Soybean, Conv. Till & $5.96 \times 10^{4}$ & $2.52 \times 10^{3}$ & $3.36 \times 10^{1}$ & 0 \\
Switchgrass, No N Fert. & $5.67 \times 10^{4}$ & $3.24 \times 10^{3}$ & $1.10 \times 10^{1}$ & 0 \\
Switchgrass, With N Fert. & $6.07 \times 10^{4}$ & $3.23 \times 10^{3}$ & $1.28 \times 10^{1}$ & 0 \\
\hline
\end{tabular}

is highest for the continuous corn, conventional tillage cropping system, due to the increase in $\mathrm{NO}_{2}$ emissions from the use of farm equipment.

\subsection{Forest ecosystem model}

Carbon sequestration by reforested land was modeled at the regional scale, using the iTree Design software suite and functions to predict tree height and crown diameter. [65,66] Six tree species native to Ohio that were considered in this study include white oak, Scots pine, American elm, spruce, birch and eastern hemlock. [67] Tree height and crown diameter were estimated for each tree species using height-age and diameter-height functions for twenty year old open grown trees. [66] Climate regulation and air quality regulation supplies per tree, under average conditions for west-central Ohio, were then estimated per tree using the iTree design tool. [68] Reforestation was assumed to create no ecosystem service demand regardless of tree species. The ecosystem service supplies are given in Table 5 .

Table 5: Ecosystem service demand and supply from reforestation over twenty years.

\begin{tabular}{l|c|c|c|c}
\hline \multirow{2}{*}{ Tree Species } & \multicolumn{2}{|c|}{$\begin{array}{c}\text { Climate Regulation } \\
\left(\mathrm{kg} \mathrm{CO} \text { - }^{2} / \text { tree }\right)\end{array}$} & \multicolumn{2}{|c}{$\begin{array}{c}\text { Air Quality Regulation } \\
(\mathrm{kg} \mathrm{NO} / \text { tree })\end{array}$} \\
\cline { 2 - 5 } & Demand & Supply & Demand & Supply \\
\hline White oak & 0 & $1.61 \times 10^{4}$ & 0 & 2.96 \\
Scots pine & 0 & $8.65 \times 10^{4}$ & 0 & 2.94 \\
American elm & 0 & $1.23 \times 10^{4}$ & 0 & 2.96 \\
Spruce & 0 & $1.31 \times 10^{4}$ & 0 & 2.97 \\
Birch & 0 & $1.19 \times 10^{4}$ & 0 & 2.93 \\
Eastern hemlock & 0 & $5.24 \times 10^{4}$ & 0 & 3.00 \\
\hline
\end{tabular}

\subsection{Scale of ecosystem services}

The scale at which the ecosystem service demand and supply is modeled depends on the largest scale which is relevant for that service and for which data is available. For the system considered 
here, the climate regulation demand is quantified with emissions of two greenhouse gases, nitrous oxide $\left(\mathrm{N}_{2} \mathrm{O}\right)$ and carbon dioxide $\left(\mathrm{CO}_{2}\right) . \mathrm{N}_{2} \mathrm{O}$ emissions are modeled at the local and regional scales. $\mathrm{N}_{2} \mathrm{O}$ emissions were not included at the economy scale due to a lack of data, and because at that scale $\mathrm{N}_{2} \mathrm{O}$ emissions are expected to be insignificant compared to $\mathrm{CO}_{2}$ emissions. $\mathrm{CO}_{2}$ emissions are modeled at all three scales, local, regional and national. The third greenhouse gas commonly accounted for, methane, was not considered in this study. Methane is produced in very low quantities by the agricultural and biomass conversion activities, and it is not taken up in significant quantities by either reforestation or agriculture. The additional climate regulation demand and supply due to the emission and sequestration of methane is thus taken as negligible compared to the demand and supply due to $\mathrm{N}_{2} \mathrm{O}$ and $\mathrm{CO}_{2}$ emission and sequestration. [69]

The supply of climate regulation, quantified by carbon sequestration, is provided only by agricultural activities and by reforestation, thus it is modeled at the regional scale. Although carbon sequestration data is available at the national scale [70], it was not included in this model due to issues related to the allocation of ecosystem service supply and the presence of carbon trading schemes that are beyond the scope of this work.

Air quality regulation is modeled only at the regional and local scales, as its serviceshed, which depends on the maximum distance of pollutant dispersion, is a relatively small spatial area. Air quality regulation demand, quantified with $\mathrm{NO}_{2}$ emissions, is created both by the farming activities and by the biomass conversion processes, while supply is provided at the regional scale by reforestation.

In accounting for $\mathrm{CO}_{2}$ emissions and carbon sequestration, all biogenic emissions and shortterm carbon sequestration are excluded. Biogenic emissions come from carbon in the biomass being converted to fuel, and the short-term carbon sequestration is provided by carbon uptake in growing crops. These emissions and sequestration are two components in the short-term carbon sequestration/emission cycle that consists of biomass growth, conversion to fuel, and fuel use. The amount of carbon involved in the cycle varies, but the amount of carbon released in biomass conversion and fuel usage is approximately equal to the carbon taken up by the next cycle of biomass growth for all energy products. Because the fuel usage phase is not included in the design boundary, the carbon balance cannot be closed for all energy products. Excluding all biogenic emissions and short-term carbon sequestration is therefore necessary to avoid giving some energy products, which do not release a significant amount of biogenic $\mathrm{CO}_{2}$ until the use phase, an unfair advantage over other products that release a greater proportion of biogenic $\mathrm{CO}_{2}$ during biomass conversion. For the same reason, carbon taken up in the biomass that gets converted to fuel or sold as food is not included in the climate regulation supply. The only $\mathrm{CO}_{2}$ emissions included in the climate regulation demand are from fossil sources, and the only carbon sequestration included in the supply is long-term sequestration in agricultural soil and in forest biomass, which is not harvested. Table 6 summarizes the scales at which the demand and supply of different ecosystem services are quantified.

\subsection{Decision variables and ranges}

Decision variables within the optimization problem are expressed as vectors. $\overline{\mathbf{s}}$ represents the amount of economic activity in each economic sector, in units of millions of USD. The vector $\underline{\mathbf{s}}$ represents the acreage of each cropping system and the numbers of wind turbines and of solar panels installed:

$$
\underline{\mathbf{s}}=\left[\begin{array}{llllllll}
\underline{s}_{\mathrm{CCNT}} & \underline{s}_{\mathrm{CCCT}} & \underline{s}_{\mathrm{CSNT}} & \underline{s}_{\mathrm{CSCT}} & \underline{s}_{\mathrm{SNF}} & \underline{s}_{\mathrm{SWF}} & \underline{s}_{\mathrm{WT}}^{I} & \underline{s}_{\mathrm{SP}}^{I}
\end{array}\right]^{T} .
$$


Table 6: Scale of component models and ecosystem services.

\begin{tabular}{l|l|l|l}
\hline Scale & Component Models & Climate Regulation & Air Quality Regulation \\
\hline Local & Biomass Conversion Processes & Demand & Demand \\
\hline \multirow{3}{*}{ Regional } & Farming Activities & Demand and Supply & Demand \\
& Wind Turbines & assumed negligible & assumed negligible \\
& Solar Panels & assumed negligible & assumed negligible \\
& Reforestation & Supply & Supply \\
\hline National & Life Cycle Activities & Demand & \\
\hline
\end{tabular}

Elements of $\underline{\mathbf{s}}$ correspond to the land use activities shown in red (both ovals and rectangles) in Figure 1. The superscript $I$ indicates that the wind turbine and solar panel scaling factors are integer variables; the rest of the land use scaling factors are continuous variables. $\underline{\mathbf{t}}$ represents the number of trees of each tree species planted as reforestation:

$$
\underline{\mathbf{t}}=\left[\begin{array}{llllll}
\underline{t}_{\mathrm{WO}} & \underline{t}_{\mathrm{ScP}} & \underline{t}_{\mathrm{AE}} & \underline{t}_{\mathrm{Sp}} & \underline{t}_{\mathrm{Bi}} & \underline{t}_{\mathrm{EH}}
\end{array}\right]^{T} .
$$

All of the reforestation variables, which correspond to the green ovals in Figure 1, are integer variables. Finally, s represents the (unitless) scale of each biomass conversion process:

$$
\mathbf{s}=\left[\begin{array}{llllllll}
s_{\text {CornEth }} & s_{\text {SoyBiod }} & s_{\text {SwiEth }} & s_{\text {StoEth }} & s_{\text {SwiPyr }} & s_{\text {StoPyr }} & s_{\text {SwiCom }} & s_{\text {StoCom }}
\end{array}\right]^{T} .
$$

Biomass conversion plant scaling factors are constrained to be less than one:

$$
\mathbf{s} \leq 1
$$

Elements of $\mathbf{s}$ correspond to the blue rectangles shown in Figure 1. The elements of $\overline{\mathbf{s}}, \underline{\mathbf{s}}, \underline{\mathbf{t}}$ and $\mathbf{s}$ are all non-negative. Table 7 gives expanded definitions of the elements of $\underline{\mathbf{s}}, \underline{\mathbf{t}}$ and $\mathbf{s}$.

The number of wind turbines and the number of solar panels, $\underline{s}_{W T}^{I}$ and $\underline{s}_{S P}^{I}$, are constrained as follows. The number of wind turbines may not exceed 500:

$$
\underline{s}_{\mathrm{WT}}^{I} \leq 500 .
$$

This upper limit was calculated from sources given in Table 3, based on keeping a safe distance between wind turbines. An upper limit is likewise imposed on the number of solar panels:

$$
\underline{s}_{\text {SP }}^{I} \leq 57,812,156 .
$$

The limit was calculated based on the land area occupied by each solar panel unit.

\subsection{Objective functions}

The set of objective functions under Life Cycle Design and under TES Design are listed in Table 8 and are defined in Equations (16) - (21). All of the objective functions in all scenarios represent the twenty-year operating period, such that the energy production objective function represents twenty years of fuel and electricity production, climate regulation demand represents $\mathrm{CO}_{2}$ and $\mathrm{N}_{2} \mathrm{O}$ emissions from twenty years of system operation, and so on for the rest of the objective functions. 
Table 7: Definitions of variables in optimization equations. Variables are continuous unless otherwise noted.

\begin{tabular}{c|l}
\hline Term & Definition \\
\hline$\overline{\mathbf{s}}$ & Millions of dollars of economic activity from each economic sector \\
$\underline{s}_{\mathrm{CCNT}}$ & Acres of continuous corn, no tillage \\
$\underline{s}_{\mathrm{CCCT}}$ & Acres of continuous corn, conventional tillage \\
$\underline{s}_{\mathrm{CSNT}}$ & Acres of corn-soybean, no tillage \\
$\underline{s}_{\mathrm{CSCT}}$ & Acres of corn-soybean, conventional tillage \\
$\underline{s}_{\mathrm{SNF}}$ & Acres of switchgrass, no N fertilizer \\
$\underline{s}_{\mathrm{SWF}}$ & Acres of switchgrass with N fertilizer \\
$\underline{s}_{\mathrm{WT}}^{I}$ & Number of wind turbines (integer variable) \\
$\underline{s}_{\mathrm{SP}}^{I}$ & Number of solar panels (integer variable) \\
$s_{\mathrm{CornEth}}$ & Corn ethanol plant scaling factor \\
$s_{\mathrm{SoyBiod}}$ & Soybean biodiesel plant scaling factor \\
$s_{\mathrm{SwiEth}}$ & Switchgrass ethanol plant scaling factor \\
$s_{\mathrm{StoEth}}$ & Stover ethanol plant scaling factor \\
$s_{\mathrm{SwiPyr}}$ & Switchgrass pyrolysis plant scaling factor \\
$s_{\mathrm{StoPyr}}$ & Stover pyrolysis plant scaling factor \\
$s_{\mathrm{SwiCom}}$ & Switchgrass combustion plant scaling factor \\
$s_{\mathrm{StoCom}}$ & Stover combustion plant scaling factor \\
$\underline{t}_{\mathrm{WO}}$ & Number of white oak trees (integer variable) \\
$\underline{t}_{\mathrm{ScP}}$ & Number of Scots pine trees (integer variable) \\
$\underline{t}_{\mathrm{AE}}$ & Number of American elm trees (integer variable) \\
$\underline{t}_{\mathrm{Sp}}$ & Number of spruce trees (integer variable) \\
$\underline{t}_{\mathrm{Bi}}$ & Number of birch trees (integer variable) \\
$\underline{t}_{\mathrm{EH}}$ & Number of Eastern hemlock trees (integer variable) \\
\hline
\end{tabular}


Table 8: Objective functions under the Life Cycle Design and TES Design scenarios.

\begin{tabular}{l|c|c}
\hline Objective Function & Life Cycle Design & TES Design \\
\hline Maximize NPV, $Z_{\mathbf{N}}$ & $\mathrm{X}$ & $\mathrm{X}$ \\
Maximize energy production, $Z_{\mathbf{E}}$ & $\mathrm{X}$ & $\mathrm{X}$ \\
Minimize climate regulation demand, $Z_{\boldsymbol{\Delta}_{C}}$ & $\mathrm{X}$ & \\
Maximize net climate regulation supply, $Z_{\boldsymbol{\Sigma}_{C}}$ & & $\mathrm{X}$ \\
Minimize air quality regulation demand, $Z_{\boldsymbol{\Delta}_{A}}$ & $\mathrm{X}$ & $\mathrm{X}$ \\
Maximize net air quality regulation supply, $Z_{\boldsymbol{\Sigma}_{A}}$ & & \\
\hline
\end{tabular}

The objective functions in Table 8 are expressed as linear combinations of decision variables, with coefficient vectors that are specific to each function. The energy production objective function $Z_{\mathbf{E}}$ is expressed as

$$
Z_{\mathbf{E}}=\mathbf{E} \cdot\left[\begin{array}{l}
\underline{\mathbf{s}} \\
\underline{\mathbf{t}} \\
\mathbf{s}
\end{array}\right]
$$

in which $\mathbf{E}$ is a vector of energy production values: the total amount of fuel and electricity, in GGE, produced by each land use activity and biomass conversion process over twenty years. The elements of E are zero except for the wind turbines, solar panels, and biomass conversion processes, indicating that energetic end products are only directly produced by these activities.

All four of the remaining objective functions are calculated similarly to $Z_{\mathbf{E}}$. The net present value objective function is

$$
Z_{\mathbf{N}}=\mathbf{N} \cdot\left[\begin{array}{l}
\underline{\mathbf{s}} \\
\underline{\mathbf{t}} \\
\mathbf{s}
\end{array}\right]
$$

in which the elements of $\mathbf{N}$ are twenty-year net present values for each individual activity. The system NPV is thus calculated as a linear combination of the individual activities.

The climate regulation demand objective function is

$$
Z_{\Delta_{C}}=\Delta_{C} \cdot\left[\begin{array}{l}
\overline{\mathbf{s}} \\
\underline{\mathbf{s}} \\
\underline{\mathbf{t}} \\
\mathbf{s}
\end{array}\right]
$$

and the climate regulation net supply objective function is

$$
Z_{\Sigma_{C}}=\Sigma_{C} \cdot\left[\begin{array}{c}
\overline{\mathbf{s}} \\
\underline{\mathbf{s}} \\
\underline{\mathbf{t}} \\
\mathbf{s}
\end{array}\right] .
$$

Equation (18) only applies in the Life Cycle Design scenario, and Equation (19) applies only in the TES Design scenario. Elements of $\boldsymbol{\Delta}_{C}$ are the climate regulation demand for each economic sector, land use activity and biomass conversion process quantified over twenty years. As discussed in Section 3.10, the climate regulation demand consists of carbon dioxide and nitrous oxide emissions in $\mathrm{kg} \mathrm{CO}_{2}$-eq. Elements of $\boldsymbol{\Sigma}_{C}$ are the net climate regulation supply (supply minus demand, or sequestration minus emissions) for the same activities. 
Table 9: Land used (acres), energy produced (GGE) and net present value (USD) for each energy production system component.

\begin{tabular}{|c|c|c|c|c|}
\hline Component & $\begin{array}{c}\text { Land Used (ac) } \\
\boldsymbol{\Lambda}\end{array}$ & $\begin{array}{c}\text { Energy (GGE) } \\
\text { E }\end{array}$ & $\begin{array}{c}\mathrm{NPV}(\mathrm{USD}) \\
\mathbf{N}\end{array}$ & Unit \\
\hline Cont. Corn, No Till & 1 & 0 & $5.87 \times 10^{2}$ & \multirow{6}{*}{ per acre } \\
\hline Cont. Corn, Conv. Till & 1 & 0 & $6.67 \times 10^{2}$ & \\
\hline Corn-Soybean, No Till & 1 & 0 & $3.74 \times 10^{2}$ & \\
\hline Corn-Soybean, Conv. Till & 1 & 0 & $2.67 \times 10^{2}$ & \\
\hline Switchgrass, No N Fert. & 1 & 0 & $-4.88 \times 10^{2}$ & \\
\hline Switchgrass, With N Fert. & 1 & 0 & $-5.31 \times 10^{2}$ & \\
\hline Wind Turbine & 0.1633 & $4.27 \times 10^{6}$ & $-3.01 \times 10^{5}$ & \multirow{2}{*}{ per unit } \\
\hline Solar Panel & $1.73 \times 10^{-4}$ & $7.9 \times 10^{1}$ & $-7.23 \times 10^{2}$ & \\
\hline White Oak & $1.66 \times 10^{-3}$ & 0 & $-3.65 \times 10^{-1}$ & \multirow{6}{*}{ per tree } \\
\hline Scots Pine & $8.15 \times 10^{-4}$ & 0 & $-1.79 \times 10^{-1}$ & \\
\hline American Elm & $1.12 \times 10^{-3}$ & 0 & $-2.47 \times 10^{-1}$ & \\
\hline Spruce & $1.12 \times 10^{-3}$ & 0 & $-2.47 \times 10^{-1}$ & \\
\hline Birch & $7.91 \times 10^{-4}$ & 0 & $-1.74 \times 10^{-1}$ & \\
\hline Eastern Hemlock & $1.12 \times 10^{-3}$ & 0 & $-2.47 \times 10^{-1}$ & \\
\hline Corn Ethanol & - & $8.02 \times 10^{7}$ & $-6.88 \times 10^{6}$ & \multirow{8}{*}{ per plant } \\
\hline Soybean Biodiesel & - & $5.94 \times 10^{6}$ & $2.61 \times 10^{6}$ & \\
\hline Switchgrass Ethanol* & - & $8.11 \times 10^{8}$ & $-9.17 \times 10^{6}$ & \\
\hline Stover Ethanol* & - & $1.18 \times 10^{9}$ & $-9.21 \times 10^{6}$ & \\
\hline Switchgrass Pyrolysis* & - & $5.91 \times 10^{9}$ & $-3.17 \times 10^{6}$ & \\
\hline Stover Pyrolysis* & - & $5.54 \times 10^{9}$ & $-5.96 \times 10^{6}$ & \\
\hline Switchgrass Combustion & - & $1.43 \times 10^{10}$ & $-1.03 \times 10^{7}$ & \\
\hline Stover Combustion & - & $1.97 \times 10^{10}$ & $-1.03 \times 10^{7}$ & \\
\hline
\end{tabular}

* Includes energy and revenue from byproduct electricity 
Similarly, the air quality regulation demand objective function is

$$
Z_{\Delta_{A}}=\Delta_{A} \cdot\left[\begin{array}{l}
\underline{\mathbf{s}} \\
\underline{\mathbf{t}} \\
\mathbf{s}
\end{array}\right]
$$

and the net supply objective function is

$$
Z_{\boldsymbol{\Sigma}_{A}}=\boldsymbol{\Sigma}_{A} \cdot\left[\begin{array}{l}
\underline{\mathbf{s}} \\
\underline{\mathbf{t}} \\
\mathbf{s}
\end{array}\right] .
$$

Elements of $\boldsymbol{\Delta}_{A}$ are the air quality regulation demand quantified as nitrogen dioxide emissions; elements of $\boldsymbol{\Sigma}_{A}$ are the net air quality regulation supply. Equation (20) applies only to Life Cycle Design, and Equation (21) applies only to TES Design. $\overline{\mathbf{s}}$ does not appear in Equations (20) and (21), as air quality regulation has a regional serviceshed. The elements of $\boldsymbol{\Delta}_{C}, \boldsymbol{\Delta}_{A}, \boldsymbol{\Sigma}_{C}$ and $\boldsymbol{\Sigma}_{A}$ are given in Table 10, for all system components except the economic sectors. Climate regulation demand values for the economic sectors may be obtained from the authors on request. [70,71]

\section{Results and discussion}

A summary of the major results that highlights the comparison between Life Cycle Design and TES Design is shown in Figure 2. Optimal system designs for the ecosystem service objectives under both scenarios are shown in more detail in Figure 3, and additional ecosystem service results are shown in Figure 4. Additional detail on the results in this section is given in Annex A, and results not discussed in this section are given in Annex B.

\subsection{System performance}

Figure 2 summarizes the net climate regulation supply, NPV and the amount of energy produced for optimal system designs under Life Cycle Design and under TES Design. Low Energy Production and High Energy Production designs are not distinguished in Figure 2. Net air quality regulation supply is also not shown in Figure 2, but net air quality regulation supply correlates with net climate regulation supply. The text boxes in Figure 2 summarize the optimal system designs at each point, with acres of land use options and a breakdown of energy production activities.

\subsubsection{Comparison between design scenarios.}

TES Design and Life Cycle Design produced different optimal system designs for the ecosystem service objectives and identical designs for the energetic and NPV objectives, as expected. The TES Design scenario produced the only designs to reach absolute sustainability (green and orange triangles in Figure 2) under the maximum net ecosystem service supply objective functions. Positive net ecosystem service supplies for these designs indicates that including the forest ecosystem is sufficient to completely offset the ecosystem service demand created by the land use and energy production activities. In contrast, the minimum ecosystem service demand designs under Life Cycle Design (purple and yellow circles) are located in the lower left-hand quadrant of the graph, indicating negative net climate regulation supplies. Net air quality regulation supply, not shown in Figure 2, is also negative for these designs. Thus, under Life Cycle Design, emissions are minimized but still exceed the sequestration and pollutant removal capacity at the spatial scales considered. These results demonstrate that including both demand and supply of ecosystem services in the 
Table 10: Climate regulation and air quality regulation demand and net supply for each energy production system component. Climate regulation demand at the national scale was included in both the climate regulation demand and net supply objective functions, but the demand created by each sector is not shown here.

\begin{tabular}{|c|c|c|c|c|c|}
\hline \multirow[b]{2}{*}{ Component } & \multicolumn{2}{|c|}{$\begin{array}{l}\text { Climate Regulation } \\
\qquad\left(\mathrm{kg} \mathrm{CO} \mathrm{CO}_{2} \text {-eq }\right)\end{array}$} & \multicolumn{2}{|c|}{$\begin{array}{l}\text { Air Quality Regulation } \\
\left.\qquad(\operatorname{kg~NO})_{2}\right)\end{array}$} & \multirow[b]{2}{*}{ Unit } \\
\hline & $\begin{array}{c}\text { Demand } \\
\boldsymbol{\Delta}_{C}\end{array}$ & $\begin{array}{l}\text { Net Supply } \\
\boldsymbol{\Sigma}_{C}\end{array}$ & $\begin{array}{c}\text { Demand } \\
\boldsymbol{\Delta}_{A}\end{array}$ & $\begin{array}{l}\text { Net Supply } \\
\boldsymbol{\Sigma}_{A}\end{array}$ & \\
\hline Cont. Corn, No Till & $6.83 \times 10^{4}$ & $-6.57 \times 10^{4}$ & $2.28 \times 10^{1}$ & $-2.28 \times 10^{1}$ & \multirow{6}{*}{ per acre } \\
\hline Cont. Corn, Conv. Till & $7.30 \times 10^{4}$ & $-7.05 \times 10^{4}$ & $3.72 \times 10^{1}$ & $-3.72 \times 10^{1}$ & \\
\hline Corn-Soybean, No Till & $6.37 \times 10^{4}$ & $-6.10 \times 10^{4}$ & $2.26 \times 10^{1}$ & $-2.26 \times 10^{1}$ & \\
\hline Corn-Soybean, Conv. Till & $5.96 \times 10^{4}$ & $-5.70 \times 10^{4}$ & $3.36 \times 10^{1}$ & $-3.36 \times 10^{1}$ & \\
\hline Switchgrass, No N Fert. & $5.67 \times 10^{4}$ & $-5.35 \times 10^{4}$ & $1.10 \times 10^{1}$ & $-1.10 \times 10^{1}$ & \\
\hline Switchgrass, With N Fert. & $6.07 \times 10^{4}$ & $-5.75 \times 10^{4}$ & $1.28 \times 10^{1}$ & $-1.28 \times 10^{1}$ & \\
\hline Wind Turbine & 0 & 0 & 0 & 0 & \multirow{2}{*}{ per unit } \\
\hline Solar Panel & 0 & 0 & 0 & 0 & \\
\hline White Oak & 0 & $1.61 \times 10^{4}$ & 0 & 2.96 & \multirow{6}{*}{ per tree } \\
\hline Scots Pine & 0 & $8.65 \times 10^{3}$ & 0 & 2.94 & \\
\hline American Elm & 0 & $1.23 \times 10^{4}$ & 0 & 2.96 & \\
\hline Spruce & 0 & $1.31 \times 10^{4}$ & 0 & 2.97 & \\
\hline Birch & 0 & $1.19 \times 10^{4}$ & 0 & 2.93 & \\
\hline Eastern Hemlock & 0 & $5.24 \times 10^{3}$ & 0 & 3.00 & \\
\hline Corn Ethanol & $4.30 \times 10^{7}$ & $-4.30 \times 10^{7}$ & $2.63 \times 10^{4}$ & $-2.63 \times 10^{4}$ & \multirow{8}{*}{ per plant } \\
\hline Soybean Biodiesel & $9.52 \times 10^{5}$ & $-9.52 \times 10^{5}$ & $2.26 \times 10^{4}$ & $-2.26 \times 10^{4}$ & \\
\hline Switchgrass Ethanol & $5.00 \times 10^{6}$ & $-5.00 \times 10^{6}$ & $3.15 \times 10^{5}$ & $-3.15 \times 10^{5}$ & \\
\hline Stover Ethanol & $5.32 \times 10^{6}$ & $-5.32 \times 10^{6}$ & $3.28 \times 10^{5}$ & $-3.28 \times 10^{5}$ & \\
\hline Switchgrass Pyrolysis & $1.18 \times 10^{8}$ & $-1.18 \times 10^{8}$ & $1.09 \times 10^{5}$ & $-1.09 \times 10^{5}$ & \\
\hline Stover Pyrolysis & $1.26 \times 10^{8}$ & $-1.26 \times 10^{8}$ & $1.16 \times 10^{5}$ & $-1.16 \times 10^{5}$ & \\
\hline Switchgrass Combustion & $1.38 \times 10^{7}$ & $-1.38 \times 10^{7}$ & $7.87 \times 10^{5}$ & $-7.87 \times 10^{5}$ & \\
\hline Stover Combustion & $1.50 \times 10^{7}$ & $-1.50 \times 10^{7}$ & $8.53 \times 10^{5}$ & $-8.53 \times 10^{5}$ & \\
\hline
\end{tabular}




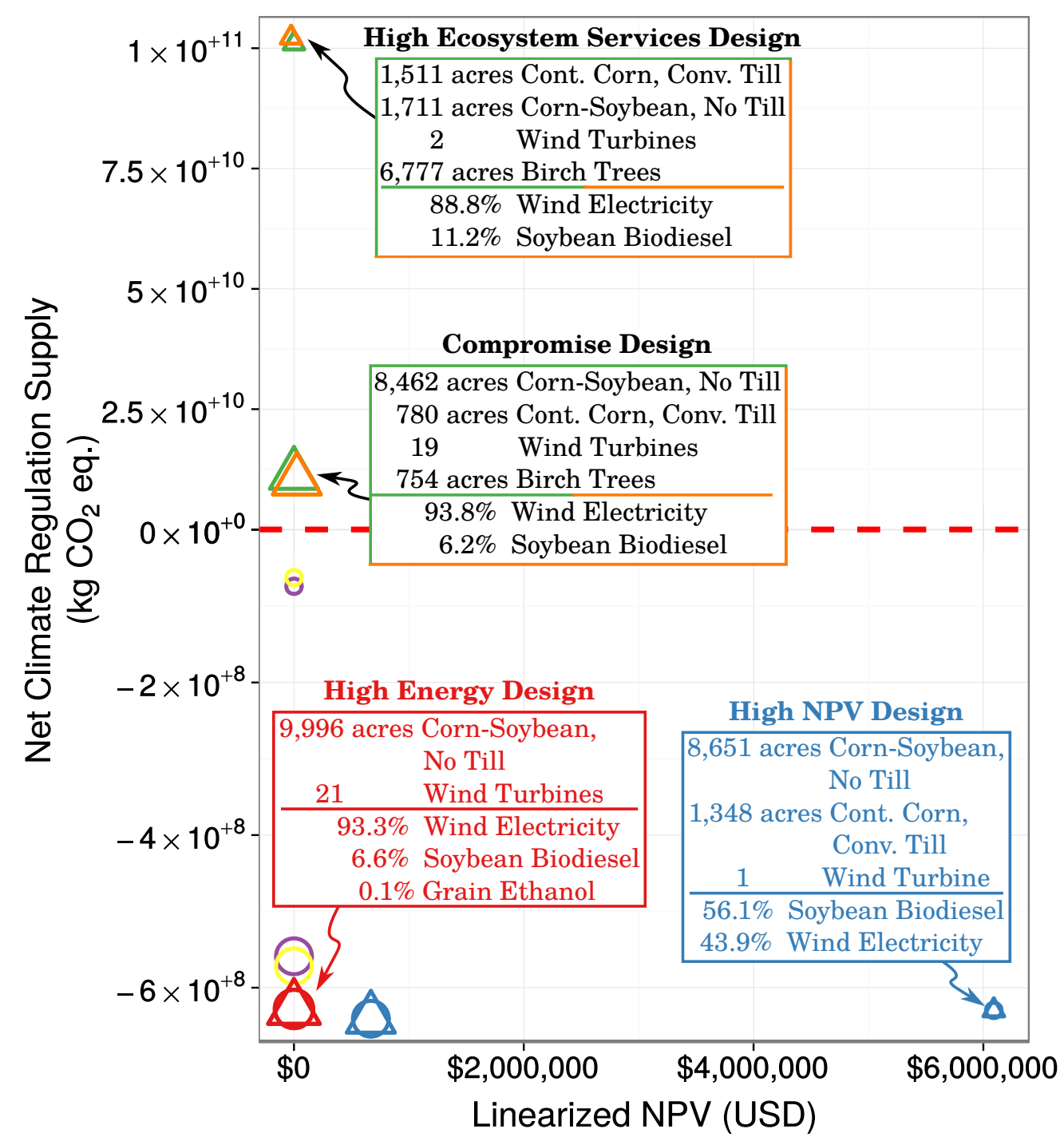

\begin{tabular}{|l||l|l|}
\hline Energy Produced (GGE) & \multicolumn{2}{|c|}{ Objective } \\
\hline O $2.5 e+07$ & Energy & NPV \\
\hline$O 5.0 e+07$ & Net Climate Reg. Supply & Climate Reg. Demand \\
\hline Net Air Quality Reg. Supply & Air Quality Reg. Demand \\
\hline
\end{tabular}

\begin{tabular}{|c|}
\hline Scenario \\
$\bigcirc$ Life Cycle Design \\
\hline$\triangle$ TES Design \\
\hline
\end{tabular}

Figure 2: Single-objective optimization results for both design scenarios. Text boxes contain summaries of the optimal designs for some points. The y-axis is broken at zero, with different scales above and below the dotted red line. Net air quality regulation supply is not shown, but designs with high net climate regulation supply also have high net air quality regulation supply. 
objective function results in more sustainable solutions that cannot be found by the conventional approach of reducing demand.

\subsubsection{Trade-off analysis.}

Figure 2 shows that while trade-offs exist between the energetic, economic and ecosystem service objectives, the trade-offs are not equal between all three objectives. In particular, for the system considered, decreasing the amount of energy produced offers ecological benefits. Designs with minimum ecosystem service demand and maximum net ecosystem service supply increase in net ecosystem service supply when energy production is reduced, and this increase in sustainability is accomplished without a corresponding decrease in NPV. However, NPV cannot be increased without a significant reduction in energy production, and the designs which maximize energy production have the worst economic performance and the next-to-worst ecological performance. It is therefore possible to increase sustainability (net ecosystem service supply) without sacrificing economic performance, but not without sacrificing the amount of energy produced.

\subsubsection{Existence of win-win-win designs.}

None of the optimal system designs result in high NPV with high energy production and positive net ecosystem service supplies, except one design, marked as a "Compromise Design" in Figure 2. This design combines positive net ecosystem service supplies with high energy production. This design represents a compromise because the NPV is zero, thus it does not provide economic, environmental and energetic benefits simultaneously. However, the presence of more than 700 acres of reforestation in the design combined with the positive net ecosystem service supply means that the NPV can be increased by reducing the amount of reforested land until one of the net ecosystem service supplies approaches or is equal to zero. At that point, the design would have a positive NPV, be energetically productive and have absolute sustainability in both ecosystem services considered, representing a win-win-win solution.

\subsection{Optimal system designs}

Figure 3 shows the production system designs obtained for the ecosystem service objective functions under Life Cycle Design and under TES Design. Details on the maximum energy and maximum NPV system designs under both scenarios are given in Annex A. The results of Figure 3 confirm that TES Design and Life Cycle Design produce unique optimal designs when optimizing for ecosystem services. When optimizing climate regulation, Life Cycle Design under Low Energy Production produces a design in which relatively little land is utilized, the the dominant cropping system is no-till corn-soybean rotation and a small number of wind turbines provide the majority of the energy. TES Design under Low Energy Production, also optimizing for climate regulation, produces a design that uses the full 10,000 acres of land and combines continuous corn under conventional tillage, no-till corn-soybean rotation and a small number of wind turbines. More than half of the acreage in this design is occupied by reforestation with birch trees. The mix of energy products under TES Design is roughly the same as that under Life Cycle Design, with wind electricity once again dominating the energy products.

Results are similar when air quality regulation is optimized under Low Energy Production. Life Cycle Design produces a system in which, once again, very little of the total land is used, and the land use is dominated by a single cropping system, no-till continuous corn, with a small amount of no-till corn soybean rotation and a few wind turbines. Energy production is again dominated by wind electricity. Optimizing air quality regulation under TES Design produces the same optimal 


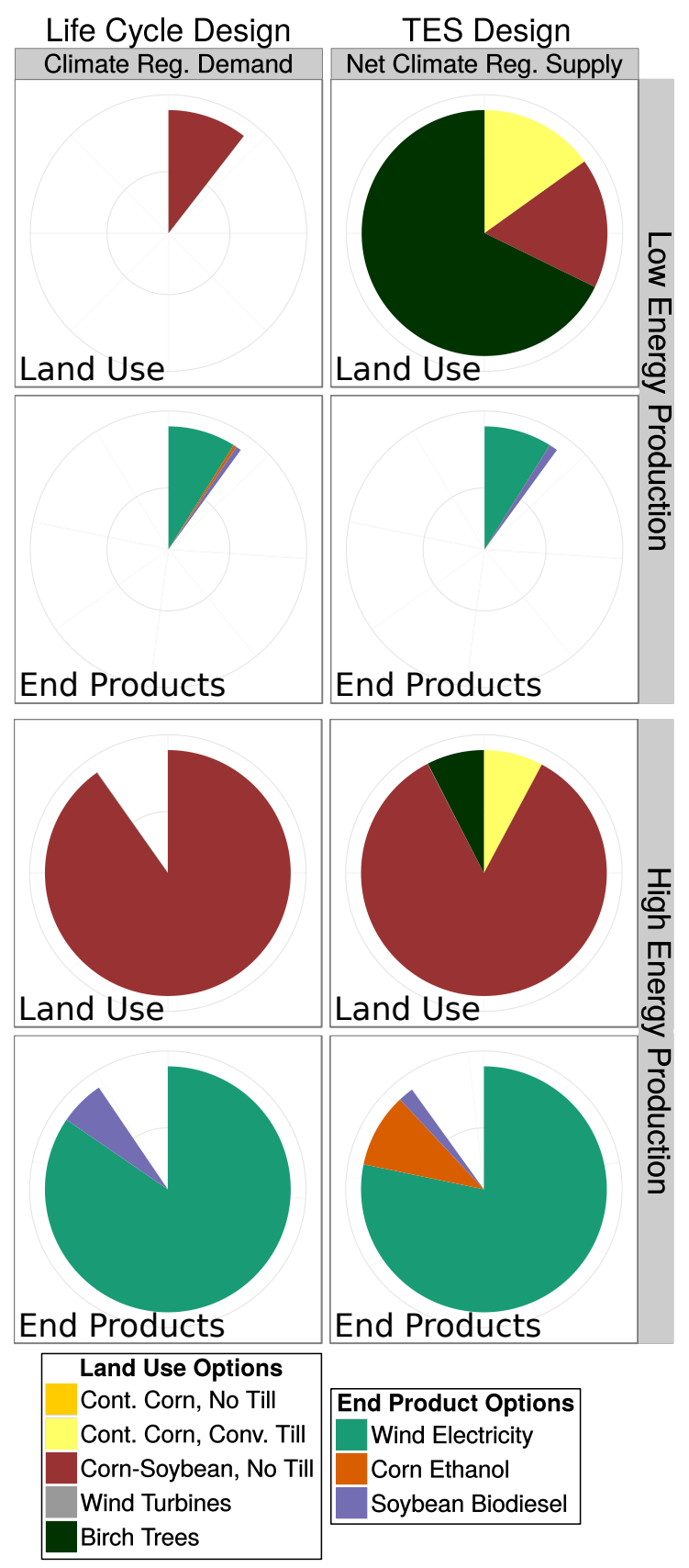

(a) Climate regulation designs

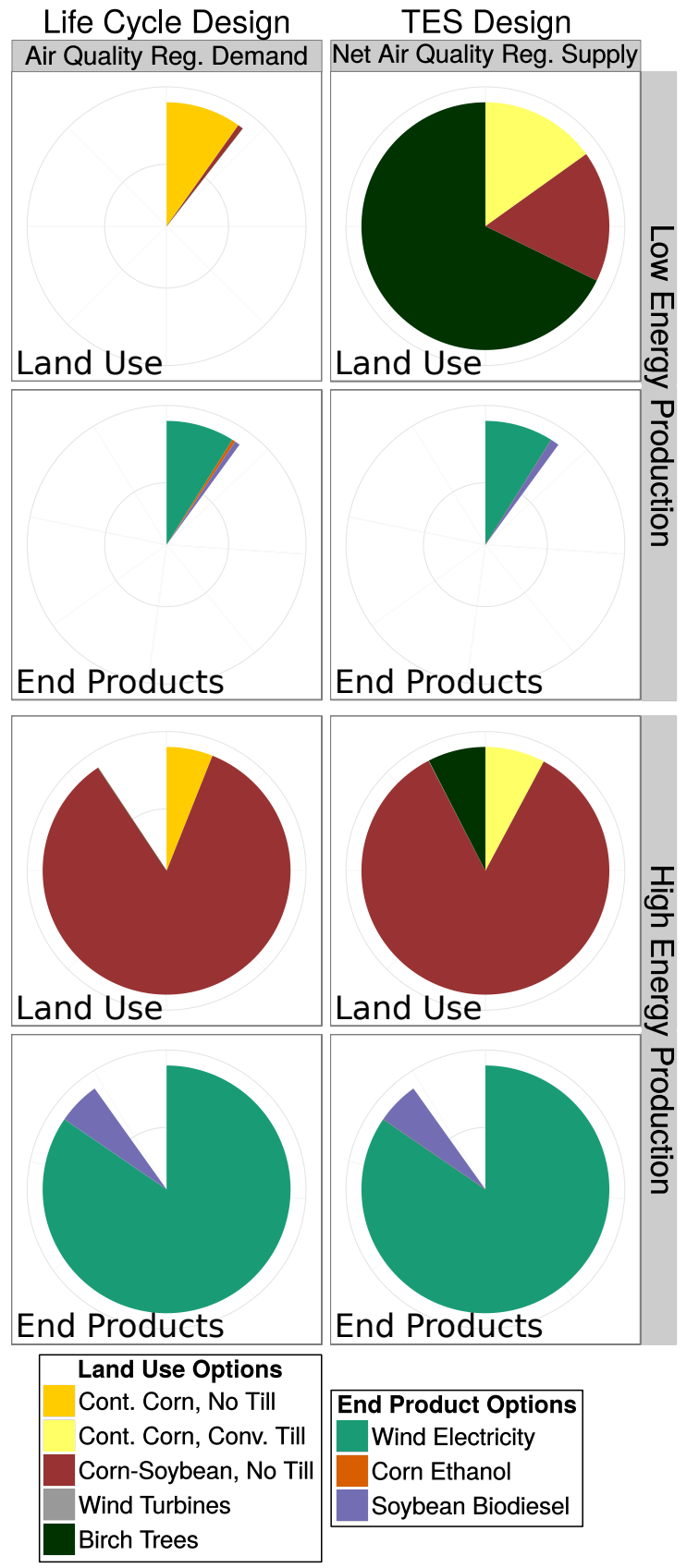

(b) Air quality regulation designs

Figure 3: System designs for ecosystem service objective functions. A fully filled-in pie chart indicates use of all 10,000 acres of land, for the land use charts, and production of the maximum amount of energy for the end product charts. 


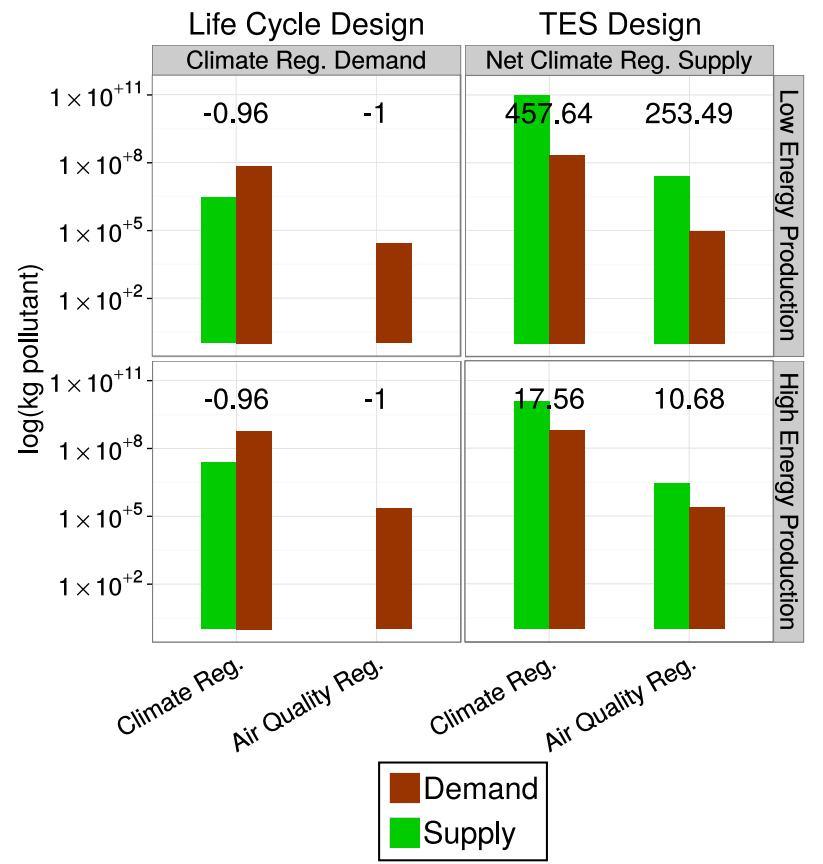

(a)

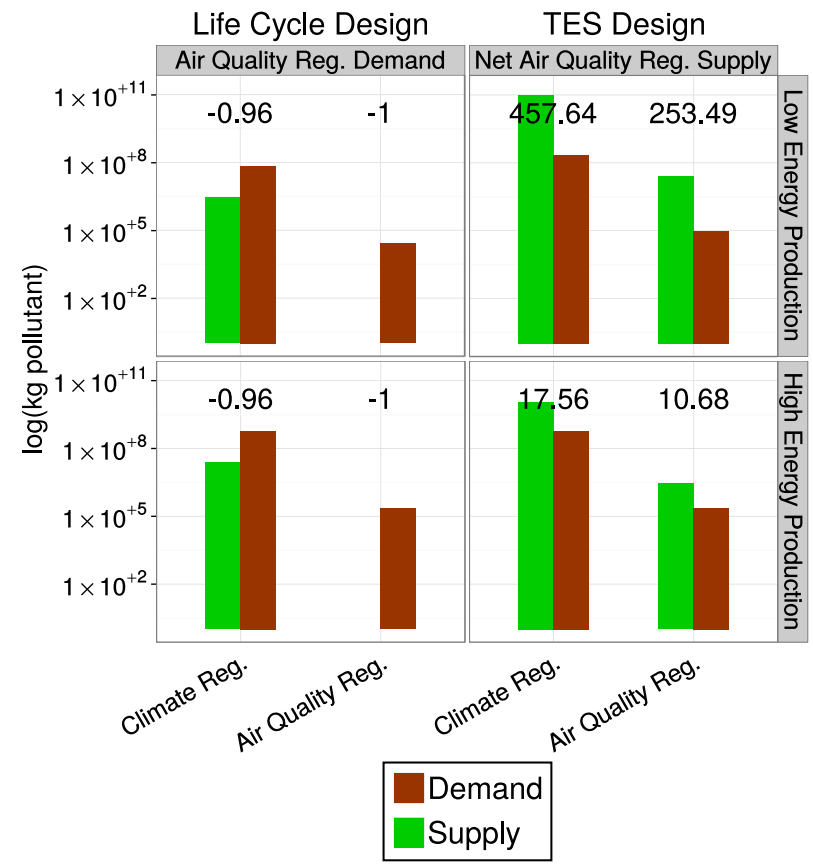

(b)

Figure 4: Ecosystem service supply, demand and sustainability index (Equation (1)) for climate regulation and air quality regulation designs. TES Design results in absolute sustainability for both ecosystem services while Life Cycle Design does not. Under TES Design, the same system design maximized the net supply of both ecosystem services.

system design as did optimizing climate regulation, with land use activities occupying the maximum amount of land and being dominated by birch tree reforestation.

Under High Energy Production, the differences between Life Cycle Design and TES Design are similar to the differences under Low Energy Production. Life Cycle Design produces systems that do not utilize the full amount of land, and the energy production is dominated by wind electricity.

Reforestation appears in every optimal system obtained under TES Design. (Under Life Cycle Design, reforestation is not permitted.) Reforestation provides only ecosystem service supply: no energetic or economic benefits result from reforestation. The presence of the reforested land allows the energy production pathways to create higher levels of demand compared to the Life Cycle Design scenario (see Figure 4 for more details), both by the use of more intensive cropping systems, such as continuous corn, conventional till, and by using a greater amount of land to produce energy. Food is also produced in each of the designs shown in Figure 3; some or all of the corn grown in each system design is sold as food rather than converted to ethanol. The sale of corn provides an additional revenue stream, which is necessary to maintain the system NPV at or above zero. Under TES Design, reforestation creates an opportunity to produce more food and the same amount of energy compared to Life Cycle Design by offsetting the additional ecosystem service demand from the more intensive corn cropping systems. These results thus demonstrate a situation in which the conventional emissions-minimizing approach leads to designs that are clearly sub-optimal. 


\subsection{Ecosystem service supply and demand}

Figure 4 shows the ecosystem service supply, demand and net supply values for the ecosystem service system designs under Life Cycle Design and TES Design. These results confirm that system designs under TES Design reach absolute sustainability, while the Life Cycle Design scenario produces optimal designs that have close to the worst possible net ecosystem service supply values: $V_{k}=-1$, indicating no significant ecosystem service supply.

The TES Design scenario results in absolute sustainability (defined in Section 3.1 as $V_{k} \geq 1$ ) due to the presence of reforestation and due to the inclusion of both supply and demand in the ecosystem service objective functions. As discussed in Section 4.2, TES Design allows for systems with higher ecosystem service demand compared to Life Cycle Demand, but the additional ecosystem service supply created by reforestation is sufficient to offset the ecosystem service demand created by the agricultural and energy production activities. This is seen in Figure 4 by comparing the Life Cycle Design and TES Design results under Low Energy Production and under High Energy Production. The sustainability index values under TES Design, for both climate regulation and air quality regulation, are consistently higher than the index values under Life Cycle Design and are also consistently greater than zero. These results indicate that reducing emissions and environmental impacts alone is insufficient for a system to reach absolute sustainability.

\subsection{Limitations}

In this work, climate regulation demand was modeled at the national scale and the supply of climate regulation, quantified by carbon sequestration service was modeled only at the regional scale, although the largest scale applicable for climate regulation is global. This simplification was made to maintain focus on decisions at scales that can be influenced more easily by regional activities. It also helped to avoid issues related to the allocation of carbon sequestration supply at the global scale, between multiple land users. Thus the climate regulation supply provided by the land considered for energy production and ecological land use activities was alone considered. Optimal design systems that have a positive net carbon regulation supply are thus sustainable within the regional boundary considered, while systems that have a negative net regulation supply may only be sustainable by considering the ecosystem service supply at larger scales. However, consideration of supply at larger scales, through activities such as supply chain management or carbon trading, is currently ignored.

Air quality regulation in reality is dependent on several types of pollutants, including particulate matter, sulfur dioxide and ozone. Due to lack of both demand and supply data for other relevant air pollutants, only $\mathrm{NO}_{2}$ emissions and sequestration was considered in this study.

The system model was formulated as a MILP, by simplifying and linearizing many of the component models. Fixed models were used for all biomass conversion activities, and the plant scaling was linearized to calculate the net present value of each plant. Ideally, models of the biomass conversion activities would include decision variables at the unit operation level, to simultaneously choose and optimize the biomass conversion process. While the P2P modeling framework is capable of capturing this extra level of complexity, converting the model from a MILP to a mixed-integer non-linear program (MINLP) by introducing non-linearities reduces the likelihood of finding global optima. The additional complexity from introducing non-linearities is unlikely to change the overall conclusions of this work.

To model farming activities, meteorological data had to be obtained for two different central Ohio locations, as sufficient data for either location over the twenty year period was not available. Because WinEPIC does not have the capability to model different rates of agricultural residue harvest, the amount of corn stover harvested under the continuous corn and corn-soybean rotation 
cropping systems was set to a fixed fraction of the total stover produced. WinEPIC also cannot model more one soil type per farming scenario, thus the soil type over the entire 10,000 acres was assumed to be homogeneous and was chosen to be the most dominant soil type in central Ohio. Interactions between the different cropping systems were not considered, nor were interactions between the reforested land and the agricultural land. The effects of land use activities on the surrounding land that also supplies ecosystem services were also not included.

Wind turbines and solar panels were assumed to have zero ecosystem service supply and demand at the farm level. In reality these options do not create ecosystem service supply, but they are likely to affect the supply and demand created by surrounding land. For instance, grass and other plants will grow around and beneath the solar panels, providing some small amount of carbon sequestration. Some recent work has demonstrated that solar panels can also be co-located with crops, which creates more opportunities for energy production. [72] However, this option is not viable in central Ohio and was not considered in this work.

\section{Conclusions and future work}

The objective of this work was to develop a methodology for TES Design and demonstrate it by application to a renewable energy system, in order to demonstrate the benefits that TES Design offers over Life Cycle Design. Results show that TES Design leads to more sustainable decisions than those obtained by Life Cycle Design. Absolute sustainability, in which the supply of ecosystem services exceeds demand for all services considered and at the largest scale modeled, was only ever reached under TES Design. Climate regulation reached a sustainability index of 457.6 and air quality regulation reached an index of 253.5 under TES Design, while the highest index values reached under Life Cycle Design were -0.96 for climate regulation and -1 for air quality regulation (the lowest possible index value is -1 ). This is because Life Cycle Design results in decisions that "do less bad" by minimizing emissions, while TES Design results in decisions that also "do more good" by balancing emissions with the capacity of ecosystems to mitigate those emissions, which also encourages the restoration and protection of ecosystems.

Results also showed that trade-offs do exist between ecosystem services, energy production, and economics, but that improving sustainability does not necessarily mean sacrificing both energy production and system economics. When land is used for ecosystem service supply as well as energy provisioning, sustainability can be increased without sacrificing economic performance. Under TES Design, which allowed for land to be used to increase ecosystem service supply, sustainability index values were increased above zero (the value which indicates absolute sustainability) while the corresponding NPV remained at zero, the same NPV achieved by minimizing emissions under Life Cycle Design. Some amount of energy production must be sacrificed to realize the sustainability benefits, but the necessary reduction in energy production is relatively small. System designs that produced the maximum possible amount of energy had sustainability indexes of -1 for both climate regulation and air quality regulation, but system designs that produced $90 \%$ of the maximum possible amount of energy reached index values of 17.6 for climate regulation and 10.7 for air quality regulation. The NPV for the maximum energy design was zero, as was the NPV for the TES Design system producing $90 \%$ of the maximum energy. The system that maximized NPV and produced $90 \%$ of the maximum energy reached an NPV of nearly $\$ 1$ million (USD( but was still unsustainable. A second major finding from this work is therefore that a small reduction in energy production intensity enables large benefits to be realized in either net ecosystem service supply or in system economics. Moreover, the "compromise design" found under the TES Design scenario results demonstrates that using land for ecosystem service supply and for energy production creates an opportunity to realize energetic, economic and ecosystem service benefits simultaneously. 
A general methodology for incorporating the TES concept into design applications, including guidelines on constructing and optimizing a TES model of an arbitrary system, is currently under development. The methodology will address not only building the model, but difficulties such as temporal and spatial scales associated with linked technological and ecological models.

One aspect of using land to produce energy that was not addressed in this work is water, both quantity and quality. Water use was not addressed because none of the land use options modeled required irrigation, and the biomass conversion facilities all had low water consumption due to internal recycling and wastewater treatment. Water quality, however, is an important issue for agriculture in general and Ohio in particular, as cyanobacteria blooms have degraded the quality of multiple bodies of water. Future work will include water quality regulation as a third ecosystem service. Demand is created through nitrate runoff from farmland, and supply can be provided either through the water quality regulation capacity of the surrounding watershed, or by a treatment wetland located on part of the farmland. Land taken up by the wetland will not be available for energy production, creating further competition between energy production and ecosystem service supply.

A system that co-produces food and energy is one way to mitigate the competition for land that exists between food and energy production. In this work, food production was not a focus, but the optimal system designs did in general co-produce food and energy. Work is ongoing to extend this energy production system design problem into a food-energy co-production system design problem, including competing food and energy production objectives. The extended problem will allow for the analysis of trade-offs between food production, energy production, ecosystem services and system economics. In addition to the climate and air quality regulation ecosystem services considered in this work, water quality regulation will be included as a third ecosystem service objective.

\section{Acknowledgements}

Partial financial support for this work was provided by the National Science Foundation (CBET1336872, CBET-1404956) and the U.S. Department of Agriculture (BRDI-2012-38202-19288). 


\section{Annex A: Details on optimal systems discussed in paper}

Table 11: System performance criteria for the minimum climate regulation demand designs (Life Cycle Design scenario) under low and high energy production.

\begin{tabular}{|c|c|c|c|}
\hline & \multicolumn{2}{|c|}{ Life Cycle Design } \\
\hline & & Low Energy & High Energy \\
\hline \multirow{2}{*}{\multicolumn{2}{|c|}{$\begin{array}{r}\text { NPV (USD) } \\
\text { Energy Produced (GGE) }\end{array}$}} & $\$ 0$ & $\$ 0$ \\
\hline & & $9,590,349$ & $86,656,550$ \\
\hline \multirow{3}{*}{ Climate Regulation (kg CO${ }_{2}$-eq) } & Demand & $69,156,229$ & $590,435,925$ \\
\hline & Supply & $2,794,306$ & $24,019,545$ \\
\hline & Sustainability Index & -0.96 & -0.96 \\
\hline \multirow{3}{*}{ Air Quality Regulation $\left(\mathrm{kg} \mathrm{NO}_{2}\right)$} & Demand & 26,330 & 224,244 \\
\hline & Supply & 0 & 0 \\
\hline & Sustainability Index & -1 & -1 \\
\hline
\end{tabular}

Table 12: System performance criteria for the minimum air quality regulation demand designs (Life Cycle Design scenario) under low and high energy production.

\begin{tabular}{|c|c|c|c|}
\hline & \multicolumn{2}{|c|}{ Life Cycle Design } \\
\hline & & Low Energy & High Energy \\
\hline \multirow{2}{*}{\multicolumn{2}{|c|}{$\begin{array}{r}\text { NPV (USD) } \\
\text { Energy Produced (GGE) }\end{array}$}} & $\$ 0$ & $\$ 0$ \\
\hline & & $9,590,349$ & $86,313,141$ \\
\hline \multirow{3}{*}{ Climate Regulation (kg CO${ }_{2}$-eq) } & Demand & $69,156,229$ & $595,948,420$ \\
\hline & Supply & $2,794,306$ & $24,066,667$ \\
\hline & Sustainability Index & -0.96 & -0.96 \\
\hline \multirow{3}{*}{ Air Quality Regulation $\left(\mathrm{kg} \mathrm{NO}_{2}\right)$} & Demand & 26,330 & 224,155 \\
\hline & Supply & 0 & 0 \\
\hline & Sustainability Index & -1 & -1 \\
\hline
\end{tabular}


Table 13: System performance criteria for the maximum net climate regulation supply system designs (TES Design scenario) under low and high energy production.

\begin{tabular}{|c|c|c|c|}
\hline & \multicolumn{2}{|c|}{ TES Design } \\
\hline & & Low Energy & High Energy \\
\hline \multirow{2}{*}{\multicolumn{2}{|c|}{$\begin{array}{r}\text { NPV (USD) } \\
\text { Energy Produced (GGE) }\end{array}$}} & $\$ 0$ & $\$ 0$ \\
\hline & & $9,590,349$ & $86,313,141$ \\
\hline \multirow{3}{*}{ Climate Regulation ( $\mathrm{kg} \mathrm{CO}$-eq) } & Demand & $221,974,980$ & $611,726,650$ \\
\hline & Supply & $101,807,608,384$ & $11,355,156,597$ \\
\hline & Sustainability Index & 458 & 18 \\
\hline \multirow{3}{*}{ Air Quality Regulation ( $\left.\mathrm{kg} \mathrm{NO}_{2}\right)$} & Demand & 98,702 & 239,369 \\
\hline & Supply & $25,118,764$ & $2,795,824$ \\
\hline & Sustainability Index & 253 & 11 \\
\hline
\end{tabular}

Table 14: System performance criteria for the maximum net air quality regulation supply system designs (TES Design scenario) under low and high energy production. These designs were identical to the maximum net climate regulation supply designs.

\begin{tabular}{|c|c|c|c|}
\hline & \multicolumn{2}{|c|}{ TES Design } \\
\hline & & Low Energy & High Energy \\
\hline & NPV (USD) & $\$ 0$ & $\$ 0$ \\
\hline Ene & rgy Produced (GGE) & $9,590,349$ & $86,313,141$ \\
\hline \multirow{3}{*}{ Climate Regulation ( $\mathrm{kg} \mathrm{CO}$-eq) } & Demand & $221,974,980$ & $611,726,650$ \\
\hline & Supply & $101,807,608,384$ & $11,355,156,597$ \\
\hline & Sustainability Index & 458 & 18 \\
\hline \multirow{3}{*}{ Air Quality Regulation $(\mathrm{kg} \mathrm{NO} 2)$} & Demand & 98,702 & 239,369 \\
\hline & Supply & $25,118,764$ & $2,795,824$ \\
\hline & Sustainability Index & 253 & 11 \\
\hline
\end{tabular}


Table 15: Minimum air quality regulation demand, Life Cycle Design, Low Energy Production

\begin{tabular}{|c|c|c|c|}
\hline \multicolumn{2}{|l|}{ Component } & Amount & Units \\
\hline \multicolumn{2}{|l|}{ Cont. Corn, No Till } & 0 & \\
\hline \multicolumn{2}{|l|}{ Cont. Corn, Conv. Till } & 0 & \\
\hline \multicolumn{2}{|l|}{ Corn-Soybean, No Till } & 1,049 & \\
\hline \multicolumn{2}{|l|}{ Corn-Soybean, Conv. Till } & 0 & acres \\
\hline \multicolumn{2}{|l|}{ Switchgrass, With N Fert. } & 0 & \\
\hline \multicolumn{2}{|l|}{ Switchgrass, No N Fert. } & 0 & \\
\hline \multicolumn{2}{|l|}{ Wind Turbines } & 2 & turbines \\
\hline \multicolumn{2}{|l|}{ Solar Panels } & 0 & panels \\
\hline \multicolumn{2}{|l|}{ White Oak } & 0 & \\
\hline \multicolumn{2}{|l|}{ Scots Pine } & 0 & \\
\hline \multicolumn{2}{|l|}{ American Elm } & 0 & \\
\hline \multicolumn{2}{|l|}{ Spruce } & 0 & acres \\
\hline \multicolumn{2}{|l|}{ Birch } & 0 & \\
\hline \multicolumn{2}{|l|}{ Eastern Hemlock } & 0 & \\
\hline \multicolumn{2}{|l|}{ Unused Land } & 8,950 & acres \\
\hline \multicolumn{2}{|l|}{ Wind Electricity } & $8,537,689$ & \multirow{16}{*}{ GGE } \\
\hline \multicolumn{2}{|l|}{ Solar Electricity } & 0 & \\
\hline \multicolumn{2}{|l|}{ Corn Grain Ethanol } & 407,175 & \\
\hline \multicolumn{2}{|l|}{ Soybean Biodiesel } & 662,799 & \\
\hline \multirow{2}{*}{$\begin{array}{l}\text { Switchgrass Ethanol } \\
\text { Switchgrass Ethanol }\end{array}$} & Ethanol & 0 & \\
\hline & Electricity & 0 & \\
\hline \multirow{2}{*}{ Stover Ethanol } & Ethanol & 0 & \\
\hline & Electricity & 0 & \\
\hline & Diesel & 0 & \\
\hline \multirow[t]{3}{*}{ Switchgrass Pyrolysis } & Gasoline & 0 & \\
\hline & Electricity & 0 & \\
\hline & Diesel & 0 & \\
\hline \multirow[t]{2}{*}{ Stover Pyrolysis } & Gasoline & 0 & \\
\hline & Electricity & 0 & \\
\hline Switchgrass Combustion & Electricity & 0 & \\
\hline Stover Combustion & Electricity & 0 & \\
\hline Corn Grain & & 18,959 & \\
\hline Soybeans & & 0 & million tood calories \\
\hline
\end{tabular}


Table 16: Minimum climate regulation demand, Life Cycle Design, Low Energy Production. This design is identical to the minimum air quality regulation demand design under Life Cycle Design and Low Energy Production, Table 15.

\begin{tabular}{|c|c|c|c|}
\hline \multicolumn{2}{|l|}{ Component } & Amount & Units \\
\hline \multicolumn{2}{|l|}{ Cont. Corn, No Till } & 0 & \\
\hline \multicolumn{2}{|l|}{ Cont. Corn, Conv. Till } & 0 & \\
\hline \multicolumn{2}{|l|}{ Corn-Soybean, No Till } & 1,049 & \\
\hline \multicolumn{2}{|l|}{ Corn-Soybean, Conv. Till } & 0 & acres \\
\hline \multicolumn{2}{|l|}{ Switchgrass, With N Fert. } & 0 & \\
\hline \multicolumn{2}{|l|}{ Switchgrass, No N Fert. } & 0 & \\
\hline \multicolumn{2}{|l|}{ Wind Turbines } & 2 & turbines \\
\hline \multicolumn{2}{|l|}{ Solar Panels } & 0 & panels \\
\hline \multicolumn{2}{|l|}{ White Oak } & 0 & \\
\hline \multicolumn{2}{|l|}{ Scots Pine } & 0 & \\
\hline \multicolumn{2}{|l|}{ American Elm } & 0 & \\
\hline \multicolumn{2}{|l|}{ Spruce } & 0 & acres \\
\hline \multicolumn{2}{|l|}{ Birch } & 0 & \\
\hline \multicolumn{2}{|l|}{ Eastern Hemlock } & 0 & \\
\hline \multicolumn{2}{|l|}{ Unused Land } & 8,950 & acres \\
\hline \multicolumn{2}{|l|}{ Wind Electricity } & $8,537,689$ & \multirow{16}{*}{ GGE } \\
\hline \multicolumn{2}{|l|}{ Solar Electricity } & 0 & \\
\hline \multicolumn{2}{|l|}{ Corn Grain Ethanol } & 407,175 & \\
\hline \multicolumn{2}{|l|}{ Soybean Biodiesel } & 662,799 & \\
\hline Switchgrass Ethanol & Ethanol & 0 & \\
\hline Switchgrass Ethanol & Electricity & 0 & \\
\hline \multirow{2}{*}{ Stover Ethanol } & Ethanol & 0 & \\
\hline & Electricity & 0 & \\
\hline \multirow{4}{*}{ Switchgrass Pyrolysis } & Diesel & 0 & \\
\hline & Gasoline & 0 & \\
\hline & Electricity & 0 & \\
\hline & Diesel & 0 & \\
\hline \multirow[t]{2}{*}{ Stover Pyrolysis } & Gasoline & 0 & \\
\hline & Electricity & 0 & \\
\hline Switchgrass Combustion & Electricity & 0 & \\
\hline Stover Combustion & Electricity & 0 & \\
\hline Corn Grain & & 18,959 & million fond colorioc \\
\hline Soybeans & & 0 & million food calories \\
\hline
\end{tabular}


Table 17: Minimum air quality regulation system design, Life Cycle Design, High Energy Production

\begin{tabular}{|c|c|c|c|}
\hline \multicolumn{2}{|l|}{ Component } & Amount & Units \\
\hline \multicolumn{2}{|l|}{ Cont. Corn, No Till } & 603 & \\
\hline \multicolumn{2}{|l|}{ Cont. Corn, Conv. Till } & 0 & \\
\hline \multicolumn{2}{|l|}{ Corn-Soybean, No Till } & 8,462 & \\
\hline \multicolumn{2}{|l|}{ Corn-Soybean, Conv. Till } & 0 & acres \\
\hline \multicolumn{2}{|l|}{ Switchgrass, With N Fert. } & 0 & \\
\hline \multicolumn{2}{|l|}{ Switchgrass, No N Fert. } & 0 & \\
\hline \multicolumn{2}{|l|}{ Wind Turbines } & 19 & turbines \\
\hline \multicolumn{2}{|l|}{ Solar Panels } & 0 & panels \\
\hline \multicolumn{2}{|l|}{ White Oak } & 0 & \\
\hline \multicolumn{2}{|l|}{ Scots Pine } & 0 & \\
\hline \multicolumn{2}{|l|}{ American Elm } & 0 & oroc \\
\hline \multicolumn{2}{|l|}{ Spruce } & 0 & acres \\
\hline \multicolumn{2}{|l|}{ Birch } & 0 & \\
\hline \multicolumn{2}{|l|}{ Eastern Hemlock } & 0 & \\
\hline \multicolumn{2}{|l|}{ Unused Land } & 931 & acres \\
\hline \multicolumn{2}{|l|}{ Wind Electricity } & $81,108,047$ & \multirow{16}{*}{ GGE } \\
\hline \multicolumn{2}{|l|}{ Solar Electricity } & 0 & \\
\hline \multicolumn{2}{|l|}{ Corn Grain Ethanol } & 0 & \\
\hline \multicolumn{2}{|l|}{ Soybean Biodiesel } & $5,344,723$ & \\
\hline Switchgrass Ethanol & Ethanol & 0 & \\
\hline Switchgrass Ethanol & Electricity & 0 & \\
\hline \multirow{2}{*}{ Stover Ethanol } & Ethanol & 0 & \\
\hline & Electricity & 0 & \\
\hline & Diesel & 0 & \\
\hline \multirow[t]{3}{*}{ Switchgrass Pyrolysis } & Gasoline & 0 & \\
\hline & Electricity & 0 & \\
\hline & Diesel & 0 & \\
\hline \multirow[t]{2}{*}{ Stover Pyrolysis } & Gasoline & 0 & \\
\hline & Electricity & 0 & \\
\hline Switchgrass Combustion & Electricity & 0 & \\
\hline Stover Combustion & Electricity & 0 & \\
\hline Corn Grain & & 219,984 & million food calories \\
\hline Soybeans & & 0 & minion rood calories \\
\hline
\end{tabular}


Table 18: Minimum climate regulation demand design, Life Cycle Design, High Energy Production.

\begin{tabular}{|c|c|c|c|}
\hline \multicolumn{2}{|l|}{ Component } & Amount & Units \\
\hline \multicolumn{2}{|l|}{ Cont. Corn, No Till } & 0 & \\
\hline \multicolumn{2}{|l|}{ Cont. Corn, Conv. Till } & 0 & \\
\hline \multicolumn{2}{|l|}{ Corn-Soybean, No Till } & 9,020 & \\
\hline \multicolumn{2}{|l|}{ Corn-Soybean, Conv. Till } & 0 & acres \\
\hline \multicolumn{2}{|l|}{ Switchgrass, With N Fert. } & 0 & \\
\hline \multicolumn{2}{|l|}{ Switchgrass, No N Fert. } & 0 & \\
\hline \multicolumn{2}{|l|}{ Wind Turbines } & 19 & turbines \\
\hline \multicolumn{2}{|l|}{ Solar Panels } & 0 & panels \\
\hline \multicolumn{2}{|l|}{ White Oak } & 0 & \\
\hline \multicolumn{2}{|l|}{ Scots Pine } & 0 & \\
\hline \multicolumn{2}{|l|}{ American Elm } & 0 & \\
\hline \multicolumn{2}{|l|}{ Spruce } & 0 & acres \\
\hline \multicolumn{2}{|l|}{ Birch } & 0 & \\
\hline \multicolumn{2}{|l|}{ Eastern Hemlock } & 0 & \\
\hline \multicolumn{2}{|l|}{ Unused Land } & 977 & acres \\
\hline \multicolumn{2}{|l|}{ Wind Electricity } & $81,108,047$ & \multirow{16}{*}{ GGE } \\
\hline \multicolumn{2}{|l|}{ Solar Electricity } & 0 & \\
\hline \multicolumn{2}{|l|}{ Corn Grain Ethanol } & 0 & \\
\hline \multicolumn{2}{|l|}{ Soybean Biodiesel } & $5,697,345$ & \\
\hline \multirow{2}{*}{$\begin{array}{l}\text { Swlchgrass Etnanol } \\
\text { Switchgrass Ethanol }\end{array}$} & Ethanol & 0 & \\
\hline & Electricity & 0 & \\
\hline \multirow{2}{*}{ Stover Ethanol } & Ethanol & 0 & \\
\hline & Electricity & 0 & \\
\hline & Diesel & 0 & \\
\hline \multirow[t]{3}{*}{ Switchgrass Pyrolysis } & Gasoline & 0 & \\
\hline & Electricity & 0 & \\
\hline & Diesel & 0 & \\
\hline \multirow[t]{2}{*}{ Stover Pyrolysis } & Gasoline & 0 & \\
\hline & Electricity & 0 & \\
\hline Switchgrass Combustion & Electricity & 0 & \\
\hline Stover Combustion & Electricity & 0 & \\
\hline Corn Grain & & 202,451 & \\
\hline Soybeans & & 0 & million tood calories \\
\hline
\end{tabular}


Table 19: Maximum net air quality regulation supply system design, TES Design, Low Energy Production.

\begin{tabular}{|c|c|c|c|}
\hline \multicolumn{2}{|l|}{ Component } & Amount & Units \\
\hline \multicolumn{2}{|l|}{ Cont. Corn, No Till } & 0 & \\
\hline \multicolumn{2}{|l|}{ Cont. Corn, Conv. Till } & 1,511 & \\
\hline \multicolumn{2}{|l|}{ Corn-Soybean, No Till } & 1,711 & \\
\hline \multicolumn{2}{|l|}{ Corn-Soybean, Conv. Till } & 0 & acres \\
\hline \multicolumn{2}{|l|}{ Switchgrass, With N Fert. } & 0 & \\
\hline \multicolumn{2}{|l|}{ Switchgrass, No N Fert. } & 0 & \\
\hline \multicolumn{2}{|l|}{ Wind Turbines } & 2 & turbines \\
\hline \multicolumn{2}{|l|}{ Solar Panels } & 0 & panels \\
\hline \multicolumn{2}{|l|}{ White Oak } & 0 & \\
\hline \multicolumn{2}{|l|}{ Scots Pine } & 0 & \\
\hline \multicolumn{2}{|l|}{ American Elm } & 0 & \\
\hline \multicolumn{2}{|l|}{ Spruce } & 0 & acres \\
\hline \multicolumn{2}{|l|}{ Birch } & 6,777 & \\
\hline \multicolumn{2}{|l|}{ Eastern Hemlock } & 0 & \\
\hline \multicolumn{2}{|l|}{ Unused Land } & 0 & acres \\
\hline \multicolumn{2}{|l|}{ Wind Electricity } & $8,537,689$ & \\
\hline \multicolumn{2}{|l|}{ Solar Electricity } & 0 & \\
\hline \multicolumn{2}{|l|}{ Corn Grain Ethanol } & 0 & \\
\hline \multicolumn{2}{|l|}{ Soybean Biodiesel } & $1,080,898$ & \\
\hline \multicolumn{2}{|l|}{ Switchgrass Ethanol } & 0 & \\
\hline \multirow[t]{2}{*}{ Switchgrass Ethanol } & Electricity & 0 & \\
\hline & Ethanol & 0 & \\
\hline \multirow{2}{*}{ Stover Ethanol } & Electricity & 0 & $\mathrm{CC \Gamma}$ \\
\hline & Diesel & 0 & GGE \\
\hline \multirow[t]{3}{*}{ Switchgrass Pyrolysis } & Gasoline & 0 & \\
\hline & Electricity & 0 & \\
\hline & Diesel & 0 & \\
\hline \multirow[t]{2}{*}{ Stover Pyrolysis } & Gasoline & 0 & \\
\hline & Electricity & 0 & \\
\hline Switchgrass Combustion & Electricity & 0 & \\
\hline Stover Combustion & Electricity & 0 & \\
\hline $\begin{array}{l}\text { Corn Grain } \\
\text { Soybeans }\end{array}$ & & $\begin{array}{c}111,310 \\
0\end{array}$ & million food calories \\
\hline
\end{tabular}


Table 20: Maximum net climate regulation supply system design, TES Design, Low Energy Production. This design is identical to the maximum net air quality regulation supply design under Low Energy Production, Table 19.

\begin{tabular}{|c|c|c|c|}
\hline \multicolumn{2}{|l|}{ Component } & Amount & Units \\
\hline \multicolumn{2}{|l|}{ Cont. Corn, No Till } & 0 & \\
\hline \multicolumn{2}{|l|}{ Cont. Corn, Conv. Till } & 1,511 & \\
\hline \multicolumn{2}{|l|}{ Corn-Soybean, No Till } & 1,711 & \\
\hline \multicolumn{2}{|l|}{ Corn-Soybean, Conv. Till } & 0 & acres \\
\hline \multicolumn{2}{|l|}{ Switchgrass, With N Fert. } & 0 & \\
\hline \multicolumn{2}{|l|}{ Switchgrass, No N Fert. } & 0 & \\
\hline \multicolumn{2}{|l|}{ Wind Turbines } & 2 & turbines \\
\hline \multicolumn{2}{|l|}{ Solar Panels } & 0 & panels \\
\hline \multicolumn{2}{|l|}{ White Oak } & 0 & \\
\hline \multicolumn{2}{|l|}{ Scots Pine } & 0 & \\
\hline \multicolumn{2}{|l|}{ American Elm } & 0 & \\
\hline \multicolumn{2}{|l|}{ Spruce } & 0 & acres \\
\hline \multicolumn{2}{|l|}{ Birch } & 6,777 & \\
\hline \multicolumn{2}{|l|}{ Eastern Hemlock } & 0 & \\
\hline \multicolumn{2}{|l|}{ Unused Land } & 0 & acres \\
\hline \multicolumn{2}{|l|}{ Wind Electricity } & $8,537,689$ & \multirow{16}{*}{ GGE } \\
\hline \multicolumn{2}{|l|}{ Solar Electricity } & 0 & \\
\hline \multicolumn{2}{|l|}{ Corn Grain Ethanol } & 0 & \\
\hline \multicolumn{2}{|l|}{ Soybean Biodiesel } & $1,080,898$ & \\
\hline Switchgrass Ethanol & Ethanol & 0 & \\
\hline Switchgrass Ethanol & Electricity & 0 & \\
\hline \multirow{2}{*}{ Stover Ethanol } & Ethanol & 0 & \\
\hline & Electricity & 0 & \\
\hline \multirow{4}{*}{ Switchgrass Pyrolysis } & Diesel & 0 & \\
\hline & Gasoline & 0 & \\
\hline & Electricity & 0 & \\
\hline & Diesel & 0 & \\
\hline \multirow[t]{2}{*}{ Stover Pyrolysis } & Gasoline & 0 & \\
\hline & Electricity & 0 & \\
\hline Switchgrass Combustion & Electricity & 0 & \\
\hline Stover Combustion & Electricity & 0 & \\
\hline Corn Grain & & 111,310 & million food calories \\
\hline Soybeans & & 0 & million food calories \\
\hline
\end{tabular}


Table 21: Maximum net air quality regulation supply system design, TES Design, High Energy Production.

\begin{tabular}{|c|c|c|c|}
\hline \multicolumn{2}{|l|}{ Component } & Amount & Units \\
\hline \multicolumn{2}{|l|}{ Cont. Corn, No Till } & 0 & \\
\hline \multicolumn{2}{|l|}{ Cont. Corn, Conv. Till } & 780 & \\
\hline \multicolumn{2}{|l|}{ Corn-Soybean, No Till } & 8,462 & acros \\
\hline \multicolumn{2}{|l|}{ Corn-Soybean, Conv. Till } & 0 & acres \\
\hline \multicolumn{2}{|l|}{ Switchgrass, With N Fert. } & 0 & \\
\hline \multicolumn{2}{|l|}{ Switchgrass, No N Fert. } & 0 & \\
\hline \multicolumn{2}{|l|}{ Wind Turbines } & 19 & turbines \\
\hline \multicolumn{2}{|l|}{ Solar Panels } & 0 & panels \\
\hline \multicolumn{2}{|l|}{ White Oak } & 0 & \\
\hline \multicolumn{2}{|l|}{ Scots Pine } & 0 & \\
\hline \multicolumn{2}{|l|}{ American Elm } & 0 & \\
\hline \multicolumn{2}{|l|}{ Spruce } & 0 & acres \\
\hline \multicolumn{2}{|l|}{ Birch } & 754 & \\
\hline \multicolumn{2}{|l|}{ Eastern Hemlock } & 0 & \\
\hline \multicolumn{2}{|l|}{ Unused Land } & 0 & acres \\
\hline \multicolumn{2}{|l|}{ Wind Electricity } & $81,108,047$ & \multirow{16}{*}{ GGE } \\
\hline \multicolumn{2}{|l|}{ Solar Electricity } & 0 & \\
\hline \multicolumn{2}{|l|}{ Corn Grain Ethanol } & 0 & \\
\hline \multicolumn{2}{|l|}{ Soybean Biodiesel } & $5,344,723$ & \\
\hline \multirow{2}{*}{$\begin{array}{l}\text { Switchgrass Ethanol } \\
\text { Switchgrass Ethanol }\end{array}$} & Ethanol & 0 & \\
\hline & Electricity & 0 & \\
\hline \multirow{2}{*}{ Stover Ethanol } & Ethanol & 0 & \\
\hline & Electricity & 0 & \\
\hline & Diesel & 0 & \\
\hline \multirow[t]{3}{*}{ Switchgrass Pyrolysis } & Gasoline & 0 & \\
\hline & Electricity & 0 & \\
\hline & Diesel & 0 & \\
\hline \multirow[t]{2}{*}{ Stover Pyrolysis } & Gasoline & 0 & \\
\hline & Electricity & 0 & \\
\hline Switchgrass Combustion & Electricity & 0 & \\
\hline Stover Combustion & Electricity & 0 & \\
\hline Corn Grain & & 227,571 & food calories \\
\hline Soybeans & & 0 & minton rood calories \\
\hline
\end{tabular}


Table 22: Maximum net climate regulation supply system design, TES Design, High Energy Production. This design is identical to the maximum net air quality regulation supply system design under High Energy Production, Table 21.

\begin{tabular}{|c|c|c|c|}
\hline \multicolumn{2}{|l|}{ Component } & Amount & Units \\
\hline \multicolumn{2}{|l|}{ Cont. Corn, No Till } & 0 & \\
\hline \multicolumn{2}{|l|}{ Cont. Corn, Conv. Till } & 780 & \\
\hline \multicolumn{2}{|l|}{ Corn-Soybean, No Till } & 8,462 & \\
\hline \multicolumn{2}{|l|}{ Corn-Soybean, Conv. Till } & 0 & acres \\
\hline \multicolumn{2}{|l|}{ Switchgrass, With N Fert. } & 0 & \\
\hline \multicolumn{2}{|l|}{ Switchgrass, No N Fert. } & 0 & \\
\hline \multicolumn{2}{|l|}{ Wind Turbines } & 19 & turbines \\
\hline \multicolumn{2}{|l|}{ Solar Panels } & 0 & panels \\
\hline \multicolumn{2}{|l|}{ White Oak } & 0 & \\
\hline \multicolumn{2}{|l|}{ Scots Pine } & 0 & \\
\hline \multicolumn{2}{|l|}{ American Elm } & 0 & \\
\hline \multicolumn{2}{|l|}{ Spruce } & 0 & acres \\
\hline \multicolumn{2}{|l|}{ Birch } & 754 & \\
\hline \multicolumn{2}{|l|}{ Eastern Hemlock } & 0 & \\
\hline \multicolumn{2}{|l|}{ Unused Land } & 0 & acres \\
\hline \multicolumn{2}{|l|}{ Wind Electricity } & $81,108,047$ & \multirow{16}{*}{ GGE } \\
\hline \multicolumn{2}{|l|}{ Solar Electricity } & 0 & \\
\hline \multicolumn{2}{|l|}{ Corn Grain Ethanol } & 0 & \\
\hline \multicolumn{2}{|l|}{ Soybean Biodiesel } & $5,344,723$ & \\
\hline Switchgrass Ethanol & Ethanol & 0 & \\
\hline Switchgrass Ethanol & Electricity & 0 & \\
\hline \multirow{2}{*}{ Stover Ethanol } & Ethanol & 0 & \\
\hline & Electricity & 0 & \\
\hline \multirow{4}{*}{ Switchgrass Pyrolysis } & Diesel & 0 & \\
\hline & Gasoline & 0 & \\
\hline & Electricity & 0 & \\
\hline & Diesel & 0 & \\
\hline \multirow[t]{2}{*}{ Stover Pyrolysis } & Gasoline & 0 & \\
\hline & Electricity & 0 & \\
\hline Switchgrass Combustion & Electricity & 0 & \\
\hline Stover Combustion & Electricity & 0 & \\
\hline Corn Grain & & 227,571 & \\
\hline Soybeans & & 0 & million food calories \\
\hline
\end{tabular}


Annex B: Details on additional optimal systems not discussed in paper 


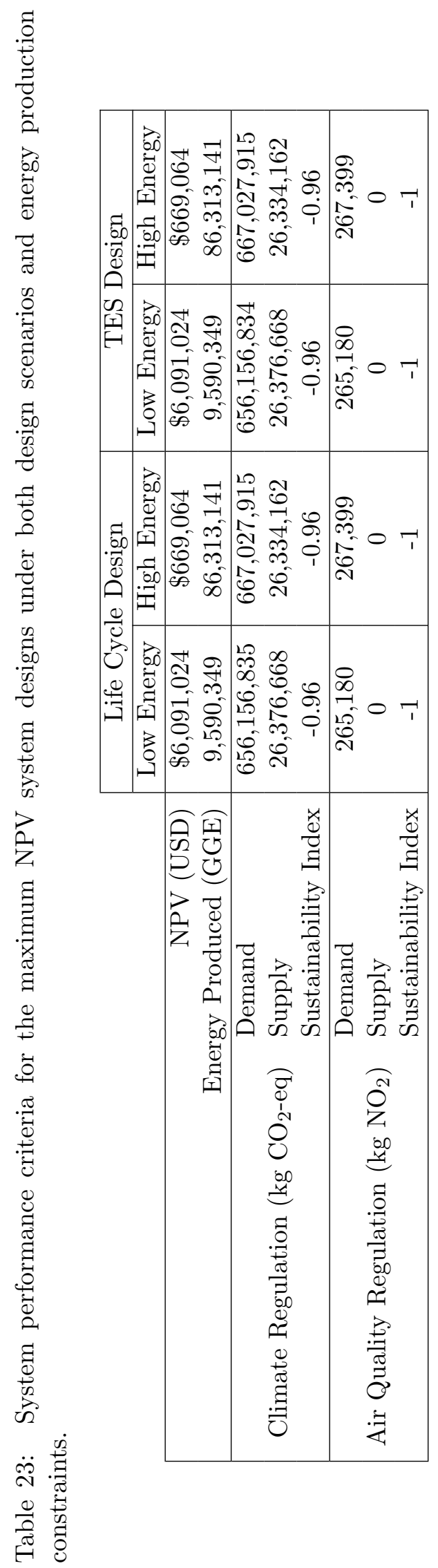




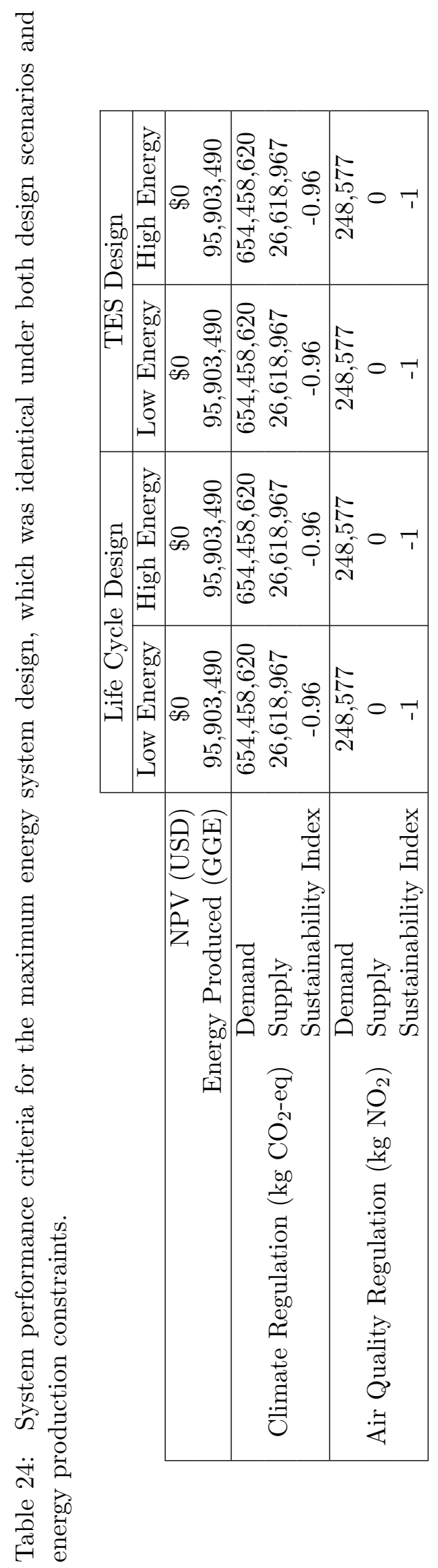


Table 25: Maximum energy system design. The maximum energy design remained the same under both design scenarios and under both energy production constraints.

\begin{tabular}{|c|c|c|c|}
\hline \multicolumn{2}{|l|}{ Component } & Amount & Units \\
\hline \multicolumn{2}{|l|}{ Cont. Corn, No Till } & 0 & \\
\hline \multicolumn{2}{|l|}{ Cont. Corn, Conv. Till } & 0 & \\
\hline \multicolumn{2}{|l|}{ Corn-Soybean, No Till } & 9,997 & soroc \\
\hline \multicolumn{2}{|l|}{ Corn-Soybean, Conv. Till } & 0 & acres \\
\hline \multicolumn{2}{|l|}{ Switchgrass, With N Fert. } & 0 & \\
\hline \multicolumn{2}{|l|}{ Switchgrass, No N Fert. } & 0 & \\
\hline \multicolumn{2}{|l|}{ Wind Turbines } & 21 & turbines \\
\hline \multicolumn{2}{|l|}{ Solar Panels } & 0 & panels \\
\hline \multicolumn{2}{|l|}{ White Oak } & 0 & \\
\hline \multicolumn{2}{|l|}{ Scots Pine } & 0 & \\
\hline \multicolumn{2}{|l|}{ American Elm } & 0 & \\
\hline \multicolumn{2}{|l|}{ Spruce } & 0 & acres \\
\hline \multicolumn{2}{|l|}{ Birch } & 0 & \\
\hline \multicolumn{2}{|l|}{ Eastern Hemlock } & 0 & \\
\hline \multicolumn{2}{|l|}{ Unused Land } & 0 & acres \\
\hline \multicolumn{2}{|l|}{ Wind Electricity } & $89,645,737$ & \multirow{16}{*}{ GGE } \\
\hline \multicolumn{2}{|l|}{ Solar Electricity } & 0 & \\
\hline \multicolumn{2}{|l|}{ Corn Grain Ethanol } & 108,785 & \\
\hline \multicolumn{2}{|l|}{ Soybean Biodiesel } & $6,313,918$ & \\
\hline \multirow{2}{*}{$\begin{array}{l}\text { Switchgrass Ethanol } \\
\text { Switchgrass Ethanol }\end{array}$} & Ethanol & 0 & \\
\hline & Electricity & 0 & \\
\hline \multirow{2}{*}{ Stover Ethanol } & Ethanol & 0 & \\
\hline & Electricity & 0 & \\
\hline & Diesel & 0 & \\
\hline \multirow[t]{3}{*}{ Switchgrass Pyrolysis } & Gasoline & 0 & \\
\hline & Electricity & 0 & \\
\hline & Diesel & 0 & \\
\hline \multirow[t]{2}{*}{ Stover Pyrolysis } & Gasoline & 0 & \\
\hline & Electricity & 0 & \\
\hline Switchgrass Combustion & Electricity & 0 & \\
\hline Stover Combustion & Electricity & 0 & \\
\hline Corn Grain & & 223,133 & million \\
\hline Soybeans & & 0 & 1 Iood calories \\
\hline
\end{tabular}


Table 26: Maximum NPV, Life Cycle Design, Low Energy Production

\begin{tabular}{|c|c|c|c|}
\hline \multicolumn{2}{|l|}{ Component } & Amount & Units \\
\hline \multicolumn{2}{|l|}{ Cont. Corn, No Till } & 0 & \\
\hline \multicolumn{2}{|l|}{ Cont. Corn, Conv. Till } & 1,348 & \\
\hline \multicolumn{2}{|l|}{ Corn-Soybean, No Till } & 8,651 & \\
\hline \multicolumn{2}{|l|}{ Corn-Soybean, Conv. Till } & 0 & acres \\
\hline \multicolumn{2}{|l|}{ Switchgrass, With N Fert. } & 0 & \\
\hline \multicolumn{2}{|l|}{ Switchgrass, No N Fert. } & 0 & \\
\hline \multicolumn{2}{|l|}{ Wind Turbines } & 1 & turbines \\
\hline \multicolumn{2}{|l|}{ Solar Panels } & 0 & panels \\
\hline \multicolumn{2}{|l|}{ White Oak } & 0 & \\
\hline \multicolumn{2}{|l|}{ Scots Pine } & 0 & \\
\hline \multicolumn{2}{|l|}{ American Elm } & 0 & م \\
\hline \multicolumn{2}{|l|}{ Spruce } & 0 & acres \\
\hline \multicolumn{2}{|l|}{ Birch } & 0 & \\
\hline \multicolumn{2}{|l|}{ Eastern Hemlock } & 0 & \\
\hline \multicolumn{2}{|l|}{ Unused Land } & 0 & acres \\
\hline \multicolumn{2}{|l|}{ Wind Electricity } & 0 & \multirow{16}{*}{ GGE } \\
\hline \multicolumn{2}{|l|}{ Solar Electricity } & 0 & \\
\hline \multicolumn{2}{|l|}{ Corn Grain Ethanol } & $5,344,723$ & \\
\hline \multicolumn{2}{|l|}{ Soybean Biodiesel } & 0 & \\
\hline \multirow{2}{*}{$\begin{array}{l}\text { Switchgrass Ethanol } \\
\text { Switchgrass Ethanol }\end{array}$} & Ethanol & 0 & \\
\hline & Electricity & 0 & \\
\hline \multirow{3}{*}{ Stover Ethanol } & Ethanol & 0 & \\
\hline & Electricity & 0 & \\
\hline & Diesel & 0 & \\
\hline \multirow[t]{3}{*}{ Switchgrass Pyrolysis } & Gasoline & 0 & \\
\hline & Electricity & 0 & \\
\hline & Diesel & 0 & \\
\hline \multirow[t]{2}{*}{ Stover Pyrolysis } & Gasoline & 0 & \\
\hline & Electricity & 0 & \\
\hline Switchgrass Combustion & Electricity & 0 & \\
\hline Stover Combustion & Electricity & 0 & \\
\hline $\begin{array}{l}\text { Corn Grain } \\
\text { Soybeans }\end{array}$ & & $\begin{array}{c}263,958 \\
0\end{array}$ & million food calories \\
\hline
\end{tabular}


Table 27: Maximum NPV system design, Life Cycle Design, High Energy Production.

\begin{tabular}{|c|c|c|c|}
\hline \multicolumn{2}{|l|}{ Component } & Amount & Units \\
\hline \multicolumn{2}{|l|}{ Cont. Corn, No Till } & 0 & \\
\hline \multicolumn{2}{|l|}{ Cont. Corn, Conv. Till } & 1,535 & \\
\hline \multicolumn{2}{|l|}{ Corn-Soybean, No Till } & 8,462 & \\
\hline \multicolumn{2}{|l|}{ Corn-Soybean, Conv. Till } & 0 & acres \\
\hline \multicolumn{2}{|l|}{ Switchgrass, With N Fert. } & 0 & \\
\hline \multicolumn{2}{|l|}{ Switchgrass, No N Fert. } & 0 & \\
\hline \multicolumn{2}{|l|}{ Wind Turbines } & 19 & turbines \\
\hline \multicolumn{2}{|l|}{ Solar Panels } & 0 & panels \\
\hline \multicolumn{2}{|l|}{ White Oak } & 0 & \\
\hline \multicolumn{2}{|l|}{ Scots Pine } & 0 & \\
\hline \multicolumn{2}{|l|}{ American Elm } & 0 & \\
\hline \multicolumn{2}{|l|}{ Spruce } & 0 & acres \\
\hline \multicolumn{2}{|l|}{ Birch } & 0 & \\
\hline \multicolumn{2}{|l|}{ Eastern Hemlock } & 0 & \\
\hline \multicolumn{2}{|l|}{ Unused Land } & 0 & acres \\
\hline \multicolumn{2}{|l|}{ Wind Electricity } & $81,108,047$ & \multirow{16}{*}{ GGE } \\
\hline \multicolumn{2}{|l|}{ Solar Electricity } & 0 & \\
\hline \multicolumn{2}{|l|}{ Corn Grain Ethanol } & 0 & \\
\hline \multicolumn{2}{|l|}{ Soybean Biodiesel } & $5,344,723$ & \\
\hline \multirow{2}{*}{$\begin{array}{l}\text { Switchgrass Ethanol } \\
\text { Switchgrass Ethanol }\end{array}$} & Ethanol & 0 & \\
\hline & Electricity & 0 & \\
\hline \multirow{2}{*}{ Stover Ethanol } & Ethanol & 0 & \\
\hline & Electricity & 0 & \\
\hline & Diesel & 0 & \\
\hline \multirow[t]{3}{*}{ Switchgrass Pyrolysis } & Gasoline & 0 & \\
\hline & Electricity & 0 & \\
\hline & Diesel & 0 & \\
\hline \multirow[t]{2}{*}{ Stover Pyrolysis } & Gasoline & 0 & \\
\hline & Electricity & 0 & \\
\hline Switchgrass Combustion & Electricity & 0 & \\
\hline Stover Combustion & Electricity & 0 & \\
\hline Corn Grain & & 263,958 & \\
\hline Soybeans & & 0 & million tood calories \\
\hline
\end{tabular}


Table 28: Maximum NPV system design, TES Design, Low Energy Production.

\begin{tabular}{|c|c|c|c|}
\hline \multicolumn{2}{|l|}{ Component } & Amount & Units \\
\hline \multicolumn{2}{|l|}{ Cont. Corn, No Till } & 0 & \\
\hline \multicolumn{2}{|l|}{ Cont. Corn, Conv. Till } & 1,348 & \\
\hline \multicolumn{2}{|l|}{ Corn-Soybean, No Till } & 8,651 & \\
\hline \multicolumn{2}{|l|}{ Corn-Soybean, Conv. Till } & 0 & acres \\
\hline \multicolumn{2}{|l|}{ Switchgrass, With N Fert. } & 0 & \\
\hline \multicolumn{2}{|l|}{ Switchgrass, No N Fert. } & 0 & \\
\hline \multicolumn{2}{|l|}{ Wind Turbines } & 1 & turbines \\
\hline \multicolumn{2}{|l|}{ Solar Panels } & 0 & panels \\
\hline \multicolumn{2}{|l|}{ White Oak } & 0 & \\
\hline \multicolumn{2}{|l|}{ Scots Pine } & 0 & \\
\hline \multicolumn{2}{|l|}{ American Elm } & 0 & \\
\hline \multicolumn{2}{|l|}{ Spruce } & 0 & acres \\
\hline \multicolumn{2}{|l|}{ Birch } & 0 & \\
\hline \multicolumn{2}{|l|}{ Eastern Hemlock } & 0 & \\
\hline \multicolumn{2}{|l|}{ Unused Land } & 0 & acres \\
\hline \multicolumn{2}{|l|}{ Wind Electricity } & $4,268,845$ & \multirow{16}{*}{ GGE } \\
\hline \multicolumn{2}{|l|}{ Solar Electricity } & 0 & \\
\hline \multicolumn{2}{|l|}{ Corn Grain Ethanol } & 0 & \\
\hline \multicolumn{2}{|l|}{ Soybean Biodiesel } & $5,464,257$ & \\
\hline Switchgrass Ethanol & Ethanol & 0 & \\
\hline Switchgrass Ethanol & Electricity & 0 & \\
\hline \multirow{2}{*}{ Stover Ethanol } & Ethanol & 0 & \\
\hline & Electricity & 0 & \\
\hline & Diesel & 0 & \\
\hline \multirow[t]{3}{*}{ Switchgrass Pyrolysis } & Gasoline & 0 & \\
\hline & Electricity & 0 & \\
\hline & Diesel & 0 & \\
\hline \multirow[t]{2}{*}{ Stover Pyrolysis } & Gasoline & 0 & \\
\hline & Electricity & 0 & \\
\hline Switchgrass Combustion & Electricity & 0 & \\
\hline Stover Combustion & Electricity & 0 & \\
\hline Corn Grain & & 259,218 & \\
\hline Soybeans & & 0 & million food calories \\
\hline
\end{tabular}


Table 29: Maximum NPV system design, TES Design, High Energy Production. This design is identical to the maximum NPV design under Life Cycle Design and High Energy Production, Table 27.

\begin{tabular}{|c|c|c|c|}
\hline \multicolumn{2}{|l|}{ Component } & Amount & Units \\
\hline \multicolumn{2}{|l|}{ Cont. Corn, No Till } & 0 & \\
\hline \multicolumn{2}{|l|}{ Cont. Corn, Conv. Till } & 1,535 & \\
\hline \multicolumn{2}{|l|}{ Corn-Soybean, No Till } & 8,462 & \\
\hline \multicolumn{2}{|l|}{ Corn-Soybean, Conv. Till } & 0 & acres \\
\hline \multicolumn{2}{|l|}{ Switchgrass, With N Fert. } & 0 & \\
\hline \multicolumn{2}{|l|}{ Switchgrass, No N Fert. } & 0 & \\
\hline \multicolumn{2}{|l|}{ Wind Turbines } & 19 & turbines \\
\hline \multicolumn{2}{|l|}{ Solar Panels } & 0 & panels \\
\hline \multicolumn{2}{|l|}{ White Oak } & 0 & \\
\hline \multicolumn{2}{|l|}{ Scots Pine } & 0 & \\
\hline \multicolumn{2}{|l|}{ American Elm } & 0 & \\
\hline \multicolumn{2}{|l|}{ Spruce } & 0 & acres \\
\hline \multicolumn{2}{|l|}{ Birch } & 0 & \\
\hline \multicolumn{2}{|l|}{ Eastern Hemlock } & 0 & \\
\hline \multicolumn{2}{|l|}{ Unused Land } & 0 & acres \\
\hline \multicolumn{2}{|l|}{ Wind Electricity } & $81,108,047$ & \multirow{16}{*}{ GGE } \\
\hline \multicolumn{2}{|l|}{ Solar Electricity } & 0 & \\
\hline \multicolumn{2}{|l|}{ Corn Grain Ethanol } & 0 & \\
\hline \multicolumn{2}{|l|}{ Soybean Biodiesel } & $5,344,723$ & \\
\hline Switchgrass Ethanol & Ethanol & 0 & \\
\hline Switchgrass Ethanol & Electricity & 0 & \\
\hline \multirow{2}{*}{ Stover Ethanol } & Ethanol & 0 & \\
\hline & Electricity & 0 & \\
\hline \multirow{4}{*}{ Switchgrass Pyrolysis } & Diesel & 0 & \\
\hline & Gasoline & 0 & \\
\hline & Electricity & 0 & \\
\hline & Diesel & 0 & \\
\hline \multirow[t]{2}{*}{ Stover Pyrolysis } & Gasoline & 0 & \\
\hline & Electricity & 0 & \\
\hline Switchgrass Combustion & Electricity & 0 & \\
\hline Stover Combustion & Electricity & 0 & \\
\hline $\begin{array}{l}\text { Corn Grain } \\
\text { Sovbeans }\end{array}$ & & $\begin{array}{c}263,958 \\
0\end{array}$ & million food calories \\
\hline
\end{tabular}




\section{References}

1. Millenium Ecosystem Assessment. Ecosystems and Human Well-being: Synthesis, 2005.

2. Johan Rockström, Will Steffen, Kevin Noone, Åsa Persson, F Stuart Chapin, Eric F Lambin, Timothy M Lenton, Marten Scheffer, Carl Folke, Hans Joachim Schellnhuber, et al. A safe operating space for humanity. Nature, 461(7263):472-475, 2009.

3. Will Steffen, Katherine Richardson, Johan Rockström, Sarah E Cornell, Ingo Fetzer, Elena M Bennett, Reinette Biggs, Stephen R Carpenter, Wim de Vries, Cynthia A de Wit, et al. Planetary boundaries: Guiding human development on a changing planet. Science, 347(6223):1259855, 2015.

4. Mathis Wackernagel, Niels B Schulz, Diana Deumling, Alejandro Callejas Linares, Martin Jenkins, Valerie Kapos, Chad Monfreda, Jonathan Loh, Norman Myers, Richard Norgaard, et al. Tracking the ecological overshoot of the human economy. Proceedings of the national Academy of Sciences, 99(14):9266-9271, 2002.

5. Alison G Power. Ecosystem services and agriculture: tradeoffs and synergies. Philosophical transactions of the royal society B: biological sciences, 365(1554):2959-2971, 2010.

6. Alexandros Gasparatos, Per Stromberg, and Kazuhiko Takeuchi. Biofuels, ecosystem services and human wellbeing: Putting biofuels in the ecosystem services narrative. Agriculture, Ecosystems ES Environment, 142(3):111-128, 2011.

7. Amalia Nikolopoulou and Marianthi G Ierapetritou. Optimal design of sustainable chemical processes and supply chains: A review. Computers \& Chemical Engineering, 44:94-103, 2012.

8. Carla Pieragostini, Miguel C Mussati, and Pío Aguirre. On process optimization considering LCA methodology. Journal of environmental management, 96(1):43-54, 2012.

9. Bhavik R Bakshi, Guy Ziv, and Michael D Lepech. Techno-ecological synergy: A framework for sustainable engineering. Environmental Science \& Technology, 49(3):17521760, 2015.

10. Doug Arent, Jacquelyn Pless, Trieu Mai, Ryan Wiser, Maureen Hand, Sam Baldwin, Garvin Heath, Jordan Macknick, Morgan Bazilian, Adam Schlosser, et al. Implications of high renewable electricity penetration in the us for water use, greenhouse gas emissions, land-use, and materials supply. Applied Energy, 123:368-377, 2014.

11. Manuel Welsch, Sebastian Hermann, Mark Howells, Hans Holger Rogner, Chester Young, I Ramma, Morgan Bazilian, G Fischer, T Alfstad, D Gielen, et al. Adding value with clewsmodelling the energy system and its interdependencies for mauritius. Applied energy, 113:1434$1445,2014$.

12. Xuesong Zhang, Roberto C Izaurralde, D Manowitz, TO West, WM Post, Allison M Thomson, Vara Prasad Bandaru, Jeff Nichols, and JR Williams. An integrative modeling framework to evaluate the productivity and sustainability of biofuel crop production systems. GCB Bioenergy, 2(5):258-277, 2010.

13. Pragnya L Eranki, David H Manowitz, Bryan D Bals, R César Izaurralde, Seungdo Kim, and Bruce E Dale. The watershed-scale optimized and rearranged landscape design (world) model and local biomass processing depots for sustainable biofuel production: Integrated life cycle assessments. Biofuels, Bioproducts and Biorefining, 7(5):537-550, 2013. 
14. Timothy D Meehan, Claudio Gratton, Erica Diehl, Natalie D Hunt, Daniel F Mooney, Stephen J Ventura, Bradford L Barham, and Randall D Jackson. Ecosystem-service tradeoffs associated with switching from annual to perennial energy crops in riparian zones of the us midwest. PloS one, 8(11):e80093, 2013.

15. Sarah C Davis, William J Parton, Stephen J Del Grosso, Cindy Keough, Ernest Marx, Paul R Adler, and Evan H DeLucia. Impact of second-generation biofuel agriculture on greenhousegas emissions in the corn-growing regions of the us. Frontiers in Ecology and the Environment, 10(2):69-74, 2011.

16. Kathrine D Behrman, Thomas E Juenger, James R Kiniry, and Timothy H Keitt. Spatial land use trade-offs for maintenance of biodiversity, biofuel, and agriculture. Landscape Ecology, 30(10):1987-1999, 2015.

17. Markus A Meyer, Tanzila Chand, and Joerg A Priess. Comparing bioenergy production sites in the southeastern us regarding ecosystem service supply and demand. PloS one, 10(3):e0116336, 2015.

18. Fengqi You, Ling Tao, Diane J Graziano, and Seth W Snyder. Optimal design of sustainable cellulosic biofuel supply chains: Multiobjective optimization coupled with life cycle assessment and input-output analysis. AIChE Journal, 58(4):1157-1180, 2012.

19. Lidija Čuček, Petar Sabev Varbanov, Jiří Jaromír Klemeš, and Zdravko Kravanja. Total footprints-based multi-criteria optimisation of regional biomass energy supply chains. Energy, 44(1):135-145, 2012.

20. Rebecca J Hanes and Bhavik R Bakshi. Sustainable process design by the process to planet framework. AIChE Journal, 61(10):3320-3331, 2015.

21. David C Howard, Paul J Burgess, Simon J Butler, Steve J Carver, Timothy Cockerill, Alastor M Coleby, Guohui Gan, CJ Goodier, Dan Van der Horst, Klaus Hubacek, et al. Energyscapes: Linking the energy system and ecosystem services in real landscapes. Biomass and Bioenergy, $55: 17-26,2013$.

22. Miao Guo, Goetz M Richter, Robert A Holland, Felix Eigenbrod, Gail Taylor, and Nilay Shah. Implementing land-use and ecosystem service effects into an integrated bioenergy value chain optimisation framework. Computers \& Chemical Engineering, 94, 2016.

23. Miguel Angel Gonzalez-Salazar, Mauro Venturini, Witold-Roger Poganietz, Matthias Finkenrath, Trevor Kirsten, Helmer Acevedo, and Pier Ruggero Spina. A general modeling framework to evaluate energy, economy, land-use and ghg emissions nexus for bioenergy exploitation. Applied Energy, 178:223-249, 2016.

24. Varsha Gopalakrishnan, Bhavik R Bakshi, and Guy Ziv. Assessing the capacity of local ecosystems to meet industrial demand for ecosystem services. AIChE Journal, 62:33193333, 2016.

25. Robert A Urban and Bhavik R Bakshi. Techno-Ecological Synergy as a Path Toward Sustainability of a North American Residential System. Environmental science $\&$ technology, 47(4):1985-1993, 2013.

26. Elias Martinez-Hernandez, Matthew Leach, and Aidong Yang. Impact of bioenergy production on ecosystem dynamics and services a case study on uk heathlands. Environmental science $\mathscr{B}$ technology, 49(9):5805-5812, 2015. 
27. Virginia H Dale, Keith L Kline, Lynn L Wright, Robert D Perlack, Mark Downing, and Robin L Graham. Interactions among bioenergy feedstock choices, landscape dynamics, and land use. Ecological Applications, 21(4):1039-1054, 2011.

28. Heather Tallis, Christina M Kennedy, Mary Ruckelshaus, Joshua Goldstein, and Joseph M Kiesecker. Mitigation for one \& all: An integrated framework for mitigation of development impacts on biodiversity and ecosystem services. Environmental Impact Assessment Review, 55:21-34, 2015 .

29. Peter Notebaert Michel Berkelaar, Kjell Eikland. lpsolve. GNU LGPL (Lesster General Public Licence), May 2005. Open source (Mixed-Integer) Linear Programming system. Multiplatform, pure ANSI C / POSIX source code, Lex/Yacc based parsing. Available at lpsolve.sourceforge.net $/ 5.5 /$.

30. Rebecca J Hanes and Bhavik R Bakshi. Process to planet: A multiscale modeling framework toward sustainable engineering. AIChE Journal, 61(10):3332-3352, 2015.

31. U.S. Bureau of Economic Analysis. Interactive tables: Input-output. http://www.bea.gov/ iTable/index_industry_io.cfm. Accessed July 25, 2014.

32. Argonne National Laboratory. Argonne GREET Model, 2015. 2015 Version. Downloaded October 2015.

33. ICIS Industries. Indicative chemical prices a-z. http://www.icis.com/chemicals/ channel-info-chemicals-a-z/ Accessed January 2015.

34. Electricity data browser: Average retail price of electricity, monthly.

35. Short-term energy outlook. table 2: U.s. energy prices. http://www.eia.gov/forecasts/ steo/tables/?tableNumber=8\#startcode=2000. Accessed May 26, 2014.

36. Petroleum \& other liquids: U.s. residual fuel oil wholesale/resale price by refiners. http://www.eia.gov/dnav/pet/hist/LeafHandler.ashx?n=pet\&s=ema_eppr_pwg_ nus_dpg\&f=a. Accessed May 26, 2014.

37. Total energy: Table 9.4, retail motor gasoline and on-highway diesel fuel prices. http://www . eia.gov/totalenergy/data/monthly/pdf/sec9_6.pdf. Accessed May 26, 2014.

38. Natural gas: Natural gas prices. http://www.eia.gov/dnav/ng/ng_pri_sum_dcu_nus_a.htm. Accessed May 26, 2014.

39. U.S. Bureau of Labor Statistics. Producer price indexes. http://www.bls.gov/ppi/home.htm. Accessed May 23, 2014.

40. L.T. Biegler, I.E. Grossmann, and A.W. Westerberg. Systematic methods for chemical process design. Carnegie Mellon Univ.,Pittsburgh, PA (United States), Dec 1997.

41. Transparent cost database. Open Energy Information (en), 2016. Accessed July 9, 2016: http://en.openei.org/wiki/Transparent_Cost_Database.

42. Caroline Draxl, Andrew Clifton, Bri-Mathias Hodge, and Jim McCaa. The wind integration national dataset (wind) toolkit. Applied Energy, 151:355-366, 2015. 
43. Erich Hau and Horst von Renouard. Wind turbines: Fundamentals, Technologies, Application, Economics, chapter Wind turbine economics, pages 845-870. Springer, 2013.

44. Wind Powering America. How to calculate wind power output, January 2010. Accessed July 8, 2016: http://www.windpowerengineering.com/construction/ calculate-wind-power-output/.

45. National Renewable Energy Laboratory. Pvwatts calculator. http://pvwatts.nrel.gov/. Accessed April 2015.

46. Andrew McAloon, Frank Taylor, Winnie Yee, Kelly Ibsen, and Robert Wooley. Determining the cost of producing ethanol from corn starch and lignocellulosic feedstocks. Technical Report NREL/TP-580-28893, National Renewable Energy Laboratory, Golden, CO, 2000.

47. A Aden, M Ruth, K Ibsen, J Jechura, K Neeves, J Sheehan, and B Montague Wallace. Lignocellulosic biomass to ethanol process design and economics utilizing co-current dilute acid prehydrolysis and enzymatic hydrolysis for corn stover. Technical Report NREL/TP-510-32438, National Renewable Energy Laboratory, Golden, CO, 2002.

48. Michael J Haas, Andrew J McAloon, Winnie C Yee, and Thomas A Foglia. A process model to estimate biodiesel production costs. Bioresource technology, 97(4):671-678, 2006.

49. EC Baker and DA Sullivan. Development of a pilot-plant process for the extraction of soy flakes with aqueous isopropyl alcohol. Journal of the American Oil Chemists Society, 60(7):1271-1277, 1983.

50. Chemstations, Inc. CHEMCAD Version 6.5, 2013. http://www . chemstations.com/. Accessed September 2013.

51. John Sheehan, Vince Camobreco, James Duffield, Michael Graboski, and Housein Shapouri. Life cycle inventory of biodiesel and petroleum diesel for use in an urban bus. final report. Technical report, National Renewable Energy Lab., Golden, CO (US), 1998.

52. David D Hsu, Daniel Inman, Garvin A Heath, Edward J Wolfrum, Margaret K Mann, and Andy Aden. Life cycle environmental impacts of selected us ethanol production and use pathways in 2022. Environmental science \& technology, 44(13):5289-5297, 2010.

53. Diego Iribarren, Jens F Peters, and Javier Dufour. Life cycle assessment of transportation fuels from biomass pyrolysis. Fuel, 97:812-821, 2012.

54. Nicole Tröger, Daniel Richter, and Ralph Stahl. Effect of feedstock composition on product yields and energy recovery rates of fast pyrolysis products from different straw types. Journal of Analytical and Applied Pyrolysis, 100:158-165, 2013.

55. M. Ringer, V. Putsche, and Scahill J. Large-scale pyrolysis oil production: A technology assessment and economic analysis. Technical Report TP-510-37779, National Renewable Energy Laboratory, November 2006.

56. R. L. Bain, W.A. Amos, M. Downing, and R.L. Perlack. Biopower technical assessment: State of the industry and technology. Technical Report TP-510-33123, National Renewable Energy Laboratory, March 2003. 
57. TJ Gerik, WL Harman, JR Williams, L Francis, J Greiner, M Magre, A Meinardus, and E Steglich. Researchers guide for winepic, version 3.0. Blackland Research and Extension Center, Temple, TX, 2006.

58. Texas A\&M University Blackland Research Center. Winepic 3.0, 2006.

59. NOAA NCDC. Climate data online [http://cdo. ncdc. noaa. gov. CDO/cdo, 2004.

60. Stephen Wilcox. National solar radiation database 1991-2005 update: User's manual. Technical report, National Renewable Energy Laboratory (NREL), Golden, CO., 2007.

61. USDA. Arms farm financial and crop production practices. Technical report, U.S. Department of Agriculture, 2015. http://www.ers.usda.gov/data-products/ arms-farm-financial-and-crop-production-practices/documentation. aspx.

62. Roque Lemus, E Charles Brummer, Kenneth J Moore, Neil E Molstad, C Lee Burras, and Michael F Barker. Biomass yield and quality of 20 switchgrass populations in southern iowa, usa. Biomass and Bioenergy, 23(6):433-442, 2002.

63. J Douglas, J Lemunyon, $\mathrm{R}$ Wynia, and $\mathrm{P}$ Salon. Planting and managing switchgrass as a biomass energy crop. usda-nrcs. Technical report, Technical note, 2009.

64. Soil Survey Staff. Web soil survey. http://websoilsurvey.nrcs.usda.gov.

65. Forest Service USDA. itree design. http://www.itreetools.org/, 2016.

66. David R Larsen and Ian R Scott. Developments to the sylvan stand structure model to describe wood-quality changes in southern bottom-land hardwood forests because of forest management. Forest Growth and Timber Quality: Crown Models and Simulation Methods for Sustainable Forest Management, page 125, 2009.

67. Common ohio trees. Ohio Department of Natural Resources: Division of Forestry, 2016. Accessed March 2015: http://forestry.ohiodnr.gov/trees.

68. iTree: Tools for assessing and manageing community forests, 2013. http://www.itreetools . org/. Accessed October 2013.

69. Millennium Ecosystem Assessment Board. Ecosystems and human well-being, volume 5. Island Press, Washington, D.D., 2005.

70. Shweta Singh and Bhavik R Bakshi. Accounting for emissions and sinks from the biogeochemical cycle of carbon in the us economic input-output model. Journal of Industrial Ecology, 18(6):818-828, 2014.

71. Eco-LCA, 2014. http://resilience.eng.ohio-state.edu/ecolca-cv/.

72. Jordan Macknick, Brenda Beatty, and Graham Hill. Overview of opportunities for co-location of solar energy technologies and vegetation. Technical Report NREL/TO-6A20-60240, National Renewable Energy Laboratory, 2013. 